\title{
Techno-Economic Viability of Agro-Photovoltaic Irrigated Arable Lands in the EU-Med Region: A Case-Study in Southwestern Spain
}

\author{
Guillermo P. Moreda ${ }^{1}$, Miguel A. Muñoz-García ${ }^{1, * \mathbb{C}}$, M. Carmen Alonso-García ${ }^{2} \mathbb{C}$ \\ and Luis Hernández-Callejo ${ }^{3}$ (D) \\ 1 LPF-TAGRALIA, Departamento de Ingeniería Agroforestal, ETS de Ingeniería Agronómica, Alimentaria y de \\ Biosistemas, Universidad Politécnica de Madrid, 28040 Madrid, Spain; guillermo.moreda@upm.es \\ 2 Unidad de Energía Solar Fotovoltaica, CIEMAT, 28040 Madrid, Spain; carmen.alonso@ciemat.es \\ 3 Departamento de Ingeniería de Sistemas y Automática, Universidad de Valladolid, 42004 Soria, Spain; \\ luis.hernandez.callejo@uva.es \\ * Correspondence: miguelangel.munoz@upm.es; Tel.: +34-9-1067-0968
}

\section{check for}

updates

Citation: Moreda, G.P.;

Muñoz-García, M.A.; Alonso-García,

M.C.; Hernández-Callejo, L.

Techno-Economic Viability of

Agro-Photovoltaic Irrigated Arable

Lands in the EU-Med Region: A

Case-Study in Southwestern Spain.

Agronomy 2021, 11, 593.

https://doi.org/10.3390/

agronomy11030593

Academic Editor: Ajit Govind

Received: 1 February 2021

Accepted: 17 March 2021

Published: 20 March 2021

Publisher's Note: MDPI stays neutral with regard to jurisdictional claims in published maps and institutional affiliations.

Copyright: (c) 2021 by the authors. Licensee MDPI, Basel, Switzerland. This article is an open access article distributed under the terms and conditions of the Creative Commons Attribution (CC BY) license (https:/ / creativecommons.org/licenses/by/ $4.0 /)$.

\begin{abstract}
Solar photovoltaic (PV) energy is positioned to play a major role in the electricity generation mix of Mediterranean countries. Nonetheless, substantial increase in ground-mounted PV installed capacity could lead to competition with the agricultural use of land. A way to avert the peril is the electricity-food dual use of land or agro-photovoltaics (APV). Here, the profitability of a hypothetical APV system deployed on irrigated arable lands of southwestern Spain is analyzed. The basic generator design, comprised of fixed-tilt opaque monofacial PV modules on a $5 \mathrm{~m}$ groundclearance substructure, featured $555.5 \mathrm{kWp} / \mathrm{ha}$. Two APV shed orientations, due south and due southwest, were compared. Two 4-year annual-crop rotations, cultivated beneath the heightened PV modules and with each rotation spanning 24 ha, were studied. One crop rotation was headed by early potato, while the other was headed by processing tomato. All 9 crops involved fulfilled the two-fold condition of being usually cultivated in the area and compatible with APV shed intermitent shading. Crop revenues under the partial shading of PV modules were derived from official average yields in the area, through the use of two alternative sets of coefficients generated for low and high crop-yield shade-induced penalty. Likewise, two irrigation water sources, surface and underground, were compared. Crop total production costs, PV system investment and operating costs and revenues from the sale of electricity, were calculated. The internal rates of return (IRRs) obtained ranged from a minimum of $3.8 \%$ for the combination of southwest orientation, early-potato rotation, groundwater and high shade-induced crop-yield penalty, to a maximum of $5.6 \%$ for the combination of south orientation, processing-tomato rotation, surface water and low shade-induced crop-yield penalty.
\end{abstract}

Keywords: agrophotovoltaic; agrivoltaic; dual-land use; solar sharing; solar photovoltaic energy; water-food-energy nexus

\section{Introduction and Objectives}

Nowadays, most countries worldwide are aware of the importance of preserving nature. Environment protection includes, amongst others, measures to limit the use of non-recyclable materials and to reduce the emission of greenhouse-effect gases (GHGs). Reduction in GHGs emission entails burning less fossil fuels and increasing the share of renewable energies in the electricity generation mix. The major renewable sources of electricity, wind and solar, intrinsically non-dispatchable due to the intermittency of their resource, could be backed-up by hydrogen fuel cells in the future. European Union (EU) member states are promoting increases in wind and solar installed capacity. Hereof, Spain and Italy planned national levels of $42 \%$ and $30 \%$, respectively, of energy from renewable sources in their gross final energy consumption in $2030[1,2]$. 
Solar power plants produce electricity based on the photovoltaic (PV) effect or by concentrating solar energy onto a heat-transfer-fluid which produces the steam that drives a turbine-generator set. In many countries, ground-mounted solar PV power plants have become familiar in the rural landscape, being popularly known as solar farms. By the end of 2019, installed solar PV power capacity in Spain stood at 8913 MW, representing about $8 \%$ of the total installed power capacity in Spain [3].

Substantial further increase in ground-mounted PV power capacity could eventually lead to conflict of interest with the agricultural use of land. This could jeopardize the stability of agricultural produce prices, which should be carefully considered. In 1982, Goetzberger and Zastrow [4] analyzed the possibility of combining agricultural and electricenergy production in the same plot. This dual use of land was later coined in the literature as agrivoltaic or agrophotovoltaic. Here, we use the latter portmanteau, abbreviated as APV. The main differences between a conventional ground-mounted PV power plant and an APV system are:

i. the spacing between PV module rows in APV systems is greater, to let more irradiation pass through and hit the crop; in conventional ground-mounted PV power plants, row spacing is kept to the minimum compatible with tolerable row self-shading.

1. the PV modules in APV systems are substantially heightened above the ground, to decrease shade intensity and also to allow agricultural machinery operate beneath; thus, while in conventional ground-mounted PV power plants the vertical distance of the modules bottom edge to the ground is $0.5-1 \mathrm{~m}$, in APV it is $5-6 \mathrm{~m}$.

In 2010, a first APV prototype was erected by Dupraz et al. in Montpellier, France [5], using fixed-tilt PV modules. In their experiments, the main crop cultivated was lettuce [6]. Valle et al. [7] reported on the extension of the Montpellier 2010 prototype with sun-tracking PV modules. In 2016, a fixed-tilt 194.4 kWp APV array with bifacial PV modules and a ground clearance of $5 \mathrm{~m}$ was erected in Herdwangen, Germany [8]. The reason for using bifacial PV modules was two-fold: First, to harness snow reflectivity to produce more electricity; and second, to decrease crop shading, thanks to higher transparency of bifacial modules compared to monofacial counterpart. Schindele et al. [8] concluded that their system was profitable for potato but not for wheat. Dinesh and Pearce [9] concluded that PV installed capacity could be increased between 40 and $70 \mathrm{GW}$ if lettuce cultivation alone were converted to APV systems in the United States of America. They recommended exploring the outputs for different crops and geographic areas, to determine the potential of APV farming worldwide. Recently, the consortium SolarPower Europe proposed to integrate a "European Agri-PV strategy" within the future Common Agricultural Policy (CAP) [10]. Hitherto, APV projects in Europe have been of limited acreage. To our knowledge, the largest APV complex, with $2.67 \mathrm{MW}$, spans 3.2 ha of raspberry near Arnhem, The Netherlands [11].

In APV systems, both the PV array and the understorey crop benefit mutually. For instance, in a watermelon field in the EU-Med region, the shade casted by the heightened PV modules could circumvent the need for anti-fruit-cracking solar protector spraying of the fruits. Apart from the economic saving for the farmer, this is beneficial for the environment. Another example of synergy is the soil moisture condition favored by APV sheds [12] that can save irrigation water. The latter is important for several reasons: First, environmental benefit; second, reduced cultivation cost; third, limited crop yield decrease in case of irrigation water allocation restricted due to drought; fourth, possibility of irrigating an acreage only slightly smaller than that of a non-drought year.

Albeit in Spain average yield per unit area of irrigated crops is 6.5 times greater than that of rainfed agriculture [13], drought episodes make granted water allocations not always deliverable. Irrigation blue water shortage is partly responsible for the difference between irrigable and irrigated area in many countries. Thus, in 2016 the share of irrigable and irrigated areas in the total Utilized Agricultural Area of Spain were of 15.7\% and $13.2 \%$ respectively [14]. In the same year 2016, the corresponding shares were $32.6 \%$ and $20.2 \%$ for Italy and of $29.7 \%$ and $23.6 \%$ for Greece. 
The objectives of this work were:

1. to design two irrigated annual crop rotations whereof crops are usually cultivated in the area of study and compatible with partial shading imposed by APV sheds.

2. to thoroughly determine the stream of expenditure and revenues for both agricultural and electricity production, with the final aim of analyzing the profitability of APV system for each combination of APV shed orientation (due south/ southwest), source of irrigation water (surface/underground), shade-induced crop yield penalty (low / high) and crop rotation (early potato/processing tomato).

\section{Materials and Methods}

A hypothetical case-study was arranged with annual irrigated crops cultivated under APV sheds in the municipality of Brenes, close to the city of Seville, in southwestern Spain. The centroid of the site sits at $37^{\circ} 33^{\prime} 22^{\prime \prime} \mathrm{N}$ and $5^{\circ} 50^{\prime} 8^{\prime \prime} \mathrm{W}$ (Datum ETRS89), standing on average altitude of $40 \mathrm{~m}$ a.s.l. Some major woody and arable crops cultivated in the area are: Olive, citrus, almond, peach, alfalfa, early potato, maize, processing tomato, cotton and sunflower. Amongst the annual arable crops, we selected potato to be rotation-head, since under-shading yield data were found in the literature [15] for this crop. Based on agronomical considerations detailed in the next sub-section, a four-year rotation headed by early-potato was designed. Taking into account the 6 ha average size of the agricultural unit plot in Brenes, a total acreage of 24 ha was analyzed. Lettuce, a shade-tolerant crop with documented under-shade yield data, was disregarded in view of its limited cultivation in the area [16]. Conversely, cotton, a traditional local annual crop, was discarded because according to Weselek et al. [17] it does not thrive in shade. For the sake of universality, we considered as if land consolidation had not been implemented in the area of study. Thereby, the spatial distribution considered is fragmented, i.e., the four 6 ha plots are not adjacent to each other (Figure 1).

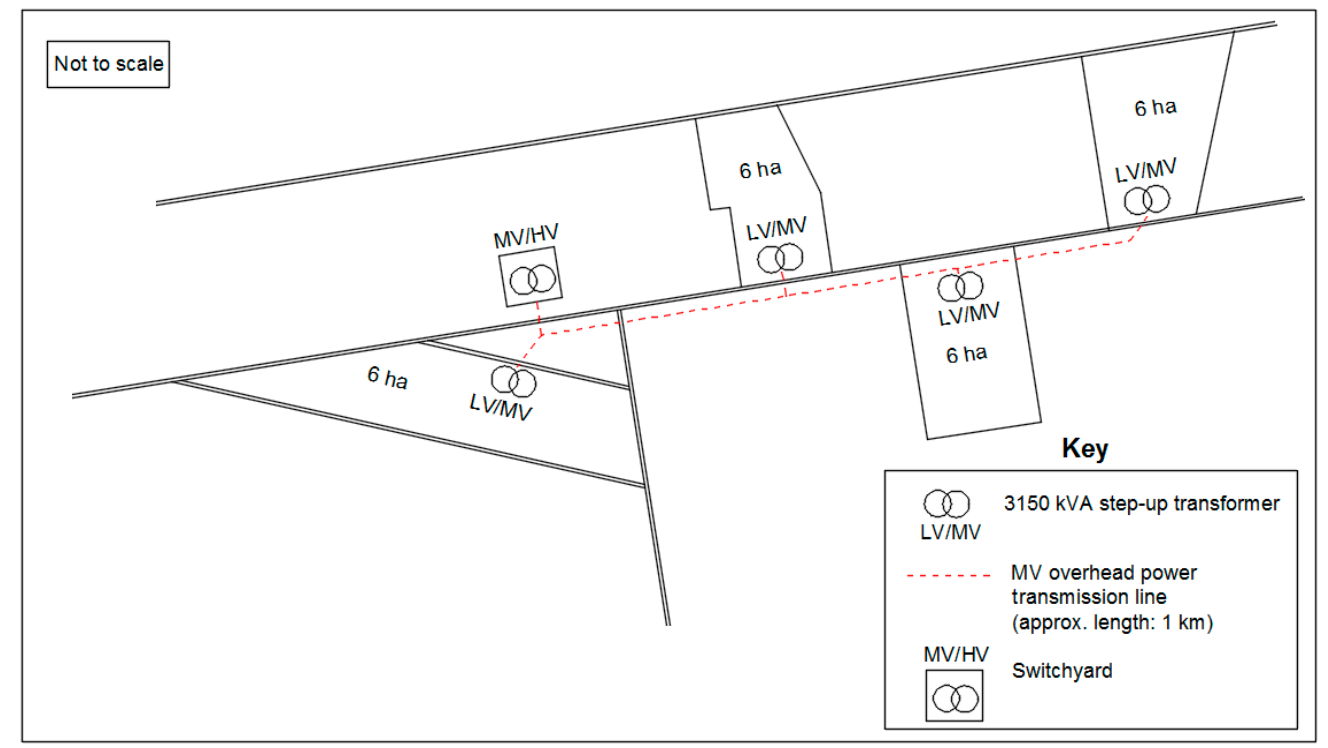

Figure 1. Spatial distribution of the four plots totalizing 24 ha, the medium voltage power transmission line budgeted and the pre-existing grid-connection switchyard.

\subsection{PV System}

The basic APV shed considered consisted of 22 non-tracking and heightened supporting structures aligned in two parallel swaths of 11 supporting structures each Figure 2. The PV modules are arranged in groups of 24 modules on each supporting structure. The fixed-tilt angle is of $27^{\circ}$ (the local latitude minus $10^{\circ}$ ). The PV module considered was the opaque-monofacial-polycrystalline CSP290-60, of $290 \mathrm{Wp}$ [18]. The dimensions of this module are $1640 \mathrm{~mm} \times 992 \mathrm{~mm}$ and it weighs $18.2 \mathrm{~kg}$. The supporting structures are 
equispaced $9.5 \mathrm{~m}$. The mechanical configuration of the basic APV shed, including lateral (Northeast-Southwest direction for the due SW shed orientation depicted) lattice bracing that leave a ground-clearance of $5 \mathrm{~m}$, is similar to the one reported by Schindele et al. [8]. This substructure is of known cost and would be valid for the location of Seville, where snow and wind loads are less or equal than in Herdwangen. The pillars of the substructure are fixed to the ground by means of a so-called spider-shaped anchor made of an anchoring bush plate with long threaded rods assembled in a circular fashion [19].

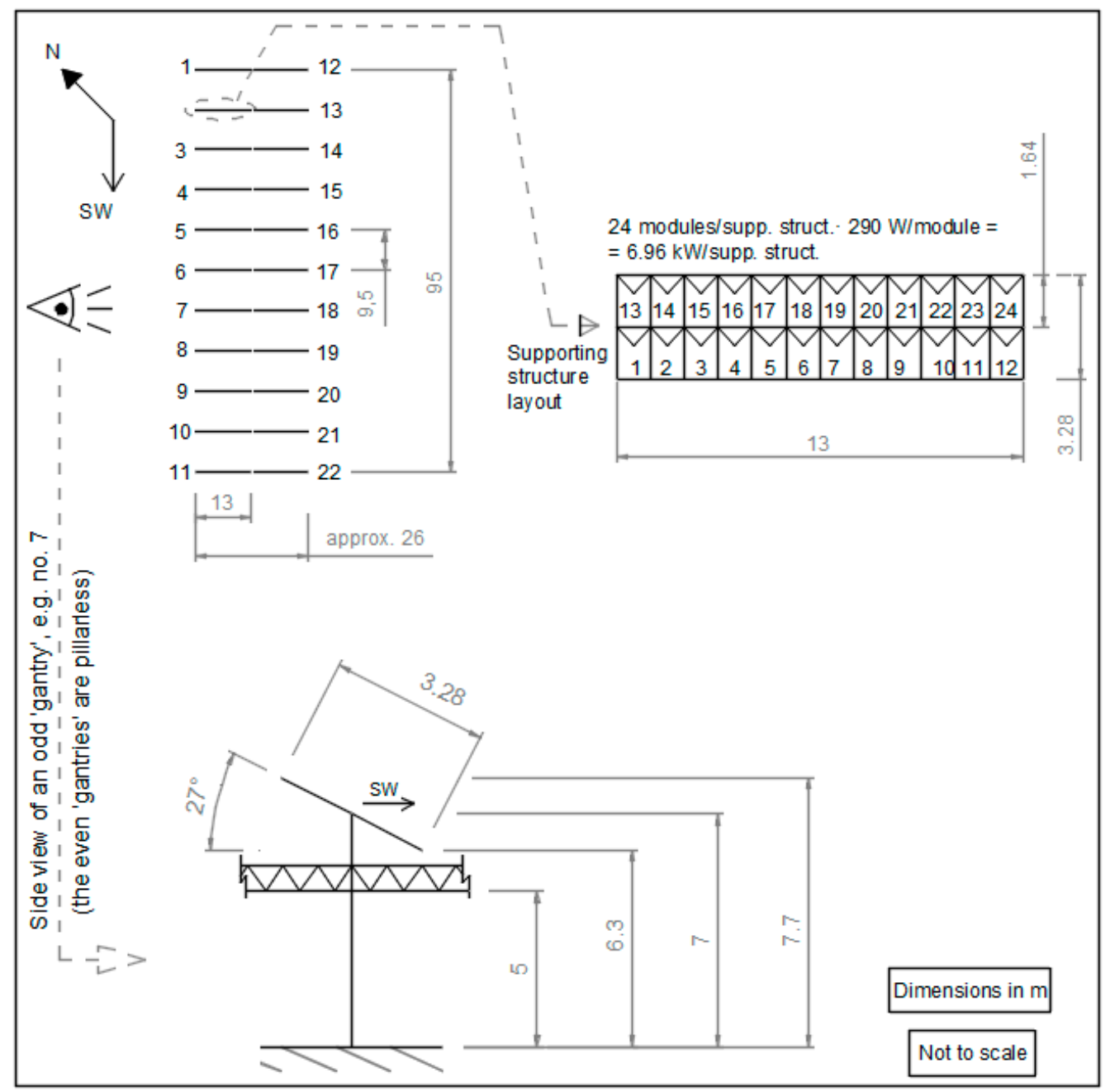

Figure 2. Basic Southwest-oriented agrophotovoltaic shed featuring an installed PV capacity of $153.1 \mathrm{kWp}$ and connected to a $150 \mathrm{~kW}$ inverter.

With regard to the PV modules azimuthal angle, two orientations were compared: due southwest and due south. Although the latter is the one that maximizes electric production in the northern hemisphere, Beck et al. [20] concluded that either southeast or southwest is preferable for the crop cultivated beneath the APV shed, since ground radiation distribution is more uniform. The increased radiation uniformity favors crop plants isochronous ripening, which is particularly important for arable crops, usually harvested in mechanized or semi-mechanized one-single pass. Here, we used SAM 3D scene shade calculator [21] to compare due South (Figure A1, Appendix A) and due Southwest (Figure A2) orientations.

The number of PV modules in the basic APV shed is

$$
24 \frac{\text { PV modules }}{\text { Supporting structure }} \cdot 22 \frac{\text { Supporting structures }}{\text { Basic APV shed }}=528 \mathrm{PV} \text { modules / Basic APV shed }
$$


The corresponding peak power is

$$
528 \frac{\text { PV modules }}{\text { Basic APV shed }} \cdot 290 \frac{\mathrm{Wp}}{\mathrm{PV} \text { module }}=153120 \mathrm{Wp} \cong 153.1 \mathrm{kWp} / \text { Basic APV shed }
$$

To calculate the ground area covered by the basic APV shed, we have to multiply its overall width ( $26 \mathrm{~m}$ (Figure 2)) by its overall length. The latter, in turn, is the sum of $95 \mathrm{~m}(10 \times 9.5 \mathrm{~m}$, Figure 2) plus $1.5 \mathrm{~m}$ (the horizontal projection of the last module row cantilever $1.64 \mathrm{~m}$ to an angle of $27^{\circ}$ ) plus $9.5 \mathrm{~m}$, i.e., $106 \mathrm{~m}$. Hence,

$$
26 \mathrm{~m} \times 106 \mathrm{~m}=2756 \mathrm{~m}^{2}=0.2756 \text { ha }
$$

To calculate the ground coverage ratio (GCR), the overall module surface area has to be first computed as:

$$
528 \mathrm{PV} \text { modules } \cdot \frac{1.68 \mathrm{~m} \cdot 0.992 \mathrm{~m}}{\mathrm{PV} \text { module }}=880 \mathrm{~m}^{2}
$$

Then, the GCR is

$$
\frac{880 \mathrm{~m}^{2}}{2756 \mathrm{~m}^{2}}=32 \%
$$

Power density is

$$
\frac{153.1 \mathrm{kWp}}{0.2756 \mathrm{ha}} \cong 555.5 \mathrm{kWp} / \mathrm{ha}
$$

Considering an effective land area of 5.7 ha, obtained by reducing by $5 \%$ the size of the agricultural unit plot to account for mismatch between plot legal boundaries and APV shed orientation, the PV capacity installed in each of the four 6 ha plots is

$$
555.5 \frac{\mathrm{kWp}}{\mathrm{ha}} \cdot 5.7 \frac{\mathrm{ha}}{\mathrm{plot}}=3166 \mathrm{kWp} / \text { plot }
$$

The inverter considered is the SMA SHP Peak 3, which features a nominal AC power of $150 \mathrm{~kW}$ [22]. The number of inverters in the agricultural unit plot would be

$$
\frac{3166 \mathrm{kWp} / \text { agricutural unit plot }}{153.1 \mathrm{kWp} / \text { inverter }} \cong 21 \text { inverters / agricultural unit plot }
$$

The lifespan considered for the APV system is 25 years, the conventional lifespan of the PV modules. The service life assigned to the inverters is 13 years, which entails inverters replacement in the year 14 . Module degradation was computed by means of a degradation coefficient, assigned a value of 1 until year 11 and annually decreased by $0.5 \%$ from the year 12 onwards. A simulation was run to estimate annual income from the sale of the energy generated by the PV system. Simulation was done using SISIFO [23], an online free simulation tool for the quality and bankability of PV systems. Table 1 presents a compilation of the main data fed to the SISIFO PV simulator.

\subsection{Irrigated Crops}

In the EU-Med countries, irrigation water use represents an average 70\% of total water withdrawals [24]. On the other hand, more than $80 \%$ of the irrigated land-acreage in Spain, involving $7 \cdot 10^{5}$ irrigators and $2 \cdot 10^{6}$-hectare, is serviced by an irrigation district [25]. According to Masia et al. [26], surface water from reservoirs represents most of the water stewardshipped and distributed by irrigation districts in the EU-Med region. Concurrently, underground water abstractions in Spain irrigate over one-third of the country irrigable area [27]. Our study is on the arable lands of the Guadalquivir river valley near Seville, where the climate is Mediterranean-oceanic [28]. According to the site coordinates, water would be served by the Comunidad de Regantes del Valle Inferior del Guadalquivir 
irrigation district, hereinafter abbreviated as Valle Inferior Irrigation District (VIID). Their irrigation scheme provides surface water with a pressure head $\left(\mathrm{p}_{\mathrm{h}}\right)$ of $441 \mathrm{kPa}$ of water measured at the pumping station [29].

Table 1. Input data for PV simulation of a 5.7 ha agro-photovoltaic plant oriented due Southwest, in Brenes (Seville, Spain).

\begin{tabular}{|c|c|}
\hline \multicolumn{2}{|l|}{ SISIFO Simulator Input Data } \\
\hline Site Geographical Latitude & $37.557351^{\circ} \mathrm{N}$ \\
\hline Site geographical longitude & $5.834142^{\circ} \mathrm{W}$ \\
\hline Local altitude $(\mathrm{m})$ & 40 \\
\hline Meteorological data type & $\mathrm{TMY}(\mathrm{a})$ \\
\hline PV system peak power $(\mathrm{kWp})$ & 3166 \\
\hline PV system peak power per inverter $(\mathrm{kWp})$ & 153.1 \\
\hline Inverter nominal power $(\mathrm{kW})$ & 150 \\
\hline Real power/peak power (dimensionless) & 0.98 \\
\hline PV system peak power per transformer $(\mathrm{kWp})$ & 3166 \\
\hline Generator inclination or PV modules tilt angle $\left(^{\circ}\right)$ & 27 \\
\hline Generator orient. or azimuth angle $\left(^{\circ}\right)$ & -45 \\
\hline Generator height at supporting structure center (m) & 7 \\
\hline Separation among structures (dimensionless) & $3^{(b)}$ \\
\hline PV generator width (dimensionless) & $8^{(\mathrm{c})}$ \\
\hline Deviation of back structure (dimensionless) & $0^{(\mathrm{d})}$ \\
\hline LV/MV transformer power (kVA) & 3150 \\
\hline $\mathrm{LV} / \mathrm{MV}$ transformer iron losses $(\mathrm{kW})$ & 32 \\
\hline $\mathrm{LV} / \mathrm{MV}$ transformer copper losses $(\mathrm{kW})$ & 32 \\
\hline DC wiring losses (\% of peak power) & 2.0 \\
\hline AC wiring losses between inverter and LV/MV transformer ( $\%$ of peak power) & 2.0 \\
\hline Soiling impact $(\%)$ & 1.0 \\
\hline
\end{tabular}

(a) Typical meteorological year. ${ }^{(b)} 9.5 \mathrm{~m} / 3.28 \mathrm{~m} \approx 3 .{ }^{\left({ }^{(c)}\right.} 26 \mathrm{~m} / 3.28 \mathrm{~m} \approx 8 .{ }^{(\mathrm{d})} 0 \mathrm{~m} / 26 \mathrm{~m}=0$.

Instead of continuous mono-cropping, a crop rotation was designed to submit to the principles of sustainable farming. The crop selected as rotation head was early-potato. To do the study more comprehensive, we extended it to an alternative four-year crop rotation. The head-of-rotation in this case was processing-tomato, which in the last years competes with early-potato in local farmers preferences. It is worthy of note that processing-tomato is also mainstream in other EU-Med countries such Italy. The main difference between the two crop rotations is that the early-potato rotation is symmetrical, unlike the processingtomato counterpart. The latter is asymmetrical because tomato withstands well—or indeed "'prefers'"- to be cultivated up to thrice on the same plot, whereas potato is required to be cultivated in a different plot each year.

The crops included in the early-potato rotation, apart from the potato (Solanum tuberosum L.) itself, were: Canola (Brassica napus), onion (Allium cepa L.), faba bean (Vicia $f a b a$ L.) and forage maize (Zea mays L.). The latter two are cultivated on the same plot one after the other in the same year, practice known as sequential cropping or double cropping (Table 2). This scheduling was designed following the sustainable agriculture principles of: (i) avoid cultivating two demanding crops one after the other in the same plot; and (ii) for every plot, avoid repeating the botanic family of the previous year.

Table 2. The early-potato rotation designed, wherein potato returns to each plot every four years.

\begin{tabular}{ccccc}
\hline Year & Plot 1 & Plot 2 & Plot 3 & Plot 4 \\
\hline 1 & FB-FM ${ }^{(a)}$ & Canola & Potato & Onion \\
2 & Canola & Potato & Onion & FB-FM \\
3 & Potato & Onion & FB-FM & Canola \\
4 & Onion & FB-FM & Canola & Potato \\
\hline
\end{tabular}

(a) Sequential cropping of faba bean (FB) in first harvest and forage maize (FM) in second harvest. 
The crops comprising the processing-tomato rotation (Table 3), apart from tomato (Lycopersicum esculentum or Solanum lycopersicum) itself, were: Melon (Cucumis melo L.), carrot (Daucus carota L.), onion and dry peas (Pisum sativum L.). Due to the asymmetry of this rotation, its full 25-year scheduling derivation is tedious and is relegated to Table A1 (Appendix B).

Table 3. Tomato rotation designed, wherein processing-tomato is cultivated in the same plot for three consecutive years.

\begin{tabular}{ccccc}
\hline Year & Plot $\mathbf{1}$ & Plot $\mathbf{2}$ & Plot $\mathbf{3}$ & Plot $\mathbf{4}$ \\
\hline 1 & Melon & Onion & Carrot & Tomato \\
2 & Onion & Carrot & Melon & Tomato \\
3 & Carrot & Melon & Onion & Tomato \\
4 & Tomato & Onion & Pea & Melon \\
\hline
\end{tabular}

\subsection{Profitability Analysis}

From an entrepreneurship point of view, an APV farm is a business comprised of two activities, namely crop production and electric power generation. To determine the profitability of an APV system, the stream of annual income and expenditure during the project lifetime has to be computed. Expenditure comprise initial investment cost (ascribed to the PV activity, since all the crops considered are annual), plus annual operation and maintenance costs (due to both agricultural and electric energy generation activities). Revenues originate from both activities and go from the second year onwards, since the first year is unproductive and carries only investment costs.

With regard to the APV system investment cost or capital expenditure (CapEx), the main items are the acquisition and installation of the substructure and mounting structures, $\mathrm{PV}$ modules, inverters, transformer and the so-called balance-of-system (cables, switchboards, etc.). Table A2 (Appendix C) includes a breakdown of the cost items involved. With regard to the operating expenditures (OpEx), they can be split in two: First, the annual PV OpEx. Second, the annual costs incurred for crop cultivation beneath APV sheds. Table 4 includes estimated crop production costs under the partial shading of an APV shed.

Table 4. Crop production cost under full sunlight and under APV partial shading (in both cases assuming irrigation with surface water).

\begin{tabular}{|c|c|c|c|c|c|c|}
\hline & \multirow{2}{*}{$\begin{array}{c}\text { Crop Production } \\
\text { Cost }{ }^{(a)} \text { under } \\
\text { Full Sunlight } \\
(€ / \text { ha) }\end{array}$} & \multicolumn{4}{|c|}{$\begin{array}{l}\text { Savings Due to Synergetic } \\
\text { APV Partial Shading }\end{array}$} & \multirow{2}{*}{$\begin{array}{c}\text { Crop Production } \\
\text { Cost under APV } \\
\text { Partial Shading } \\
\text { (€/ha) }\end{array}$} \\
\hline & & $\begin{array}{c}\text { Irrigation } \\
\text { Water Saving } \\
(\%)\end{array}$ & $\begin{array}{l}\text { Fertilization } \\
\text { Saving } \\
(\%)\end{array}$ & $\begin{array}{l}\text { Hail in Surance } \\
\text { Saving } \\
(\%)\end{array}$ & $\begin{array}{c}\text { Fruit Solar Protector } \\
\text { Saving } \\
(\%)\end{array}$ & \\
\hline Canola & 934 & $11.5^{(b)}$ & - & - & - & 931 \\
\hline Carrot & 8978 & $11.5^{(b)}$ & - & - & - & 8964 \\
\hline Forage maize & 1826 & $11.5^{(b)}$ & - & - & - & 1813 \\
\hline Dry faba bean & 544 & $11.5^{(b)}$ & - & - & - & 541 \\
\hline Melon & 7725 & $14.0^{(\mathrm{c})}$ & - & 2.5 & 1.5 & 7697 \\
\hline Onion & 7899 & $11.5^{(b)}$ & - & - & - & 7885 \\
\hline Dry pea & 631 & $11.5^{(b)}$ & - & - & - & 628 \\
\hline Early potato & 4701 & $9.0^{(\mathrm{d})}$ & - & - & - & 4694 \\
\hline Processing tomato & 4430 & $9.0^{(\mathrm{d})}$ & $2.0^{(\mathrm{e})}$ & 2.5 & - & 4403 \\
\hline
\end{tabular}

(a) See Table A4 (Appendix D) for details. ${ }^{(b)}$ Due to scarcity of bibliographic data on water saving for some crops under shade, they are assigned the mean between $14 \%$ (c) and $9 \%$ (d). (c) Assimilated to cucumber as both melon and cucumber belong to the botanical family of Cucurbitaceae; data for cucumber available at [30]. (d) Data for cherry tomato available at [31]. In addition, processing-tomato, the same value is assigned to early-potato, since the latter belongs to the same botanical family as tomato, namely, Solanaceae. ${ }^{(\mathrm{e})}$ [32].

The irrigation district is liable for pressurizing the pipeline network. Therefore, the electricity generated by the APV system would not be partially self-consumed by a pump station, but entirely sold in the electricity wholesale market. Hence, the management 
of electricity binomial tariff cost items (contracted power, energy consumption, capacity charge, meter-gauge leasing, irrigators partially exempted electric tax, etc.) is on the irrigation district behalf.

Following the recommendations/prescriptions of the EU Water Framework Directive, many irrigation districts have abandoned the traditional per-hectare flat-rate pricing. The installation of volumetric metering valves has enabled irrigation districts to change to binomial tariffs. These consist of a fixed per-hectare component that is proportional to the area with irrigation rights and a variable or volumetric component that is proportional to the volume of water used $[33,34]$.

The irrigation district determines the volumetric component, based on energy cost. This cost depends on the $\mathrm{p}_{\mathrm{h}}$ of the irrigation network, the acreage irrigated and the type of crop, since the required hydraulic power is equal to the $\mathrm{p}_{\mathrm{h}}$ multiplied by the flow rate (in turn, $\mathrm{p}_{\mathrm{h}}$ depends on whether the water source is underground or surface, the irrigated area topography (plot elevations, size and shape) and the irrigation system service pressure, e.g., sprinklers demand more pressure than drippers) For the VIID, current energy cost is of $0.012 \mathrm{EUR} / \mathrm{m}^{3}$ [35]. Rodríguez-Díaz et al. [36] measured energy consumption and power required per unit of irrigated area for several surface-water irrigation districts in southern Spain. One of them, the Bembézar Margen Derecha (BMDID), featured a $\mathrm{p}_{\mathrm{h}}$ of $461 \mathrm{kPa}$, almost identical to the VIID $\mathrm{p}_{\mathrm{h}}$ of $441 \mathrm{kPa}$. The crops irrigated are similar in both irrigation districts and similar to those of our study. In a sequel work, Fernández-García et al. [37] reported an energy cost of $0.02 \mathrm{EUR} / \mathrm{m}^{3}$ and a total irrigation cost of $283 \mathrm{EUR} / \mathrm{ha}$ for the BMDID. Here, we took the energy cost of $0.02 \mathrm{EUR} / \mathrm{m}^{3}$ [37] instead of the lower $0.012 \mathrm{EUR} / \mathrm{m}^{3}$ [35]. Total irrigation cost in sites where underground water is used is usually two-fold (600 EUR/ha) and sometimes it can reach 900 EUR/ha [38].

Apart from the energy cost, irrigation cost includes water as a fixed-cost levied upon the land. The fixed per-hectare component in turn splits in two: The royalty of the River Basin Organism (Confederación Hidrográfica del Guadalquivir), a public incumbrance for upstream public civil works that allow water disposal to irrigation schemes (42.47 EUR/ha-annum); and the irrigation district fee, for management and maintenance of downstream irrigation district proprietary pipeline network and facilities (63.23 EUR/ha.annum in the case of the VIID [35]). The sum of both amounts equals 105.8 EUR/ha-annum. Further, VIID subscribers are currently, subjected to surcharge disbursement of $84.30 \mathrm{EUR} / \mathrm{ha} \cdot$ annum in concept of amortization of pipeline, reservoirs and pumping stations upgrading works commissioned in 2008. Herein, this cost item is not included, since the expected remaining surcharge payment period is shorter than our study lifespan. In addition, regarding water use, Table 5 compiles the volumetric component and the total irrigation cost under full sunlight for the 9 crops considered.

With regard to annual revenues, the main entries are: First, the income from the sale of electricity generated by the PV modules; and second, the income originated from the sale of agricultural produce. With regard to the first, the two variables that intervene are: The annual specific energy yield $(\mathrm{kWh} / \mathrm{kWp})$ and the price perceived for the energy generated (EUR/kWh). The annual yield will decrease from year 12 onwards, due to the module degradation coefficient abovementioned. With regard to the wholesale electricity market price perceived for the energy sold, we proceeded as follows: From the future solar contracts due 2026 (FTS YR-26) published in the OMIP 2019 sessions market bulletins [42], one day per month of the year 2019 was selected for averaging. The mean of the 12 prices was 45.02 EUR/MWh (specifically, we took the 11th day of every month, except for May and August, where the 13th and 12th day, respectively, were picked, to skip the eventual Sunday effect). We deliberately dropped the 2020 sessions of the future solar market, because concerns arose about the prices thereof being convoluted with the COVID-19 effect. Afterwards, we divided the 25-year lifespan into three periods: The first one encompassing the first 9 years, while the second and third period spanning the following eight-year each. Finally, we assigned the OMIP FTS mean price previously calculated, $45.02 \mathrm{EUR} / \mathrm{MWh}$, to the first period of 9 years; a price diminished by $5 \%$ to the second 
period $(0.95 \cdot 45.02=42.77 \mathrm{EUR} / \mathrm{MWh})$; and a price diminished by $10 \%$ to the last 8 -year period $(0.90 \cdot 45.02=40.52 \mathrm{EUR} / \mathrm{MWh})$. The reason to assign the foregoing reduced prices to the second and third period is that foreseeably—and unfortunately for generators-increasing solar PV capacity installed in the forthcoming years will lead to decline of wholesale electricity prices [43].

Table 5. Irrigation costs under full sunlight.

\begin{tabular}{|c|c|c|c|c|c|}
\hline & \multirow[b]{2}{*}{$\begin{array}{l}\text { Water Use } \\
\left(\mathrm{m}^{3} / \mathrm{ha}\right)\end{array}$} & \multicolumn{2}{|c|}{ Surface Water } & \multicolumn{2}{|c|}{ Groundwater } \\
\hline & & $\begin{array}{l}\text { Energy Cost } \\
\text { (EUR/ha) }^{(b)}\end{array}$ & $\begin{array}{c}\text { Total Irrigation } \\
\text { Cost (c) } \\
\text { (EUR/ha) }\end{array}$ & $\begin{array}{l}\text { Energy Cost } \\
\text { (EUR/ha) }\end{array}$ & $\begin{array}{c}\text { Total Irrigation } \\
\text { Cost }^{(f)} \\
\text { (EUR/ha) }\end{array}$ \\
\hline Canola & 1200 & 24 & 130 & 48 & 291 \\
\hline Carrot & 6000 & 120 & 226 & 240 & 483 \\
\hline Maize & 5600 & 112 & $165^{(d)}$ & 224 & 346 \\
\hline Faba bean & 1300 & 26 & $79^{(d)}$ & 52 & 174 \\
\hline Melon & 4300 & 86 & 192 & 172 & 415 \\
\hline Onion & 5900 & 118 & 224 & 236 & 479 \\
\hline Pea & $1300^{(a)}$ & 26 & 132 & 52 & 295 \\
\hline Potato & 4000 & 80 & 186 & 160 & 403 \\
\hline Tomato & 4951 & 99 & 205 & 198 & 441 \\
\hline
\end{tabular}

(a) Following Karkanis et al. [39] and ITACYL [40]. (b) Energy cost translates into a volumetric component of 0.02 EUR/m ${ }^{3}$ [37]. (c) Fixed component: The sum of the River Basin Organism royalty plus the irrigation district fee equals 105.8 EUR/ha [35]. (d) The fixed cost is halved because faba bean and forage maize share the same field in one year. ${ }^{(e)}$ Assuming a well depth of $100 \mathrm{~m}$, energy cost translates into a volumetric component of $0.04 \mathrm{EUR} / \mathrm{m}^{3}$ [41]. ${ }^{(\mathrm{f})}$ The fixed component is related to the capacity factor charged to the irrigation district (ID) by the electric utility; in turn, the ID apportions this charge to irrigators. It is estimated as $2.3 \times 105.8 \cong 243 \mathrm{EUR} /$ ha; with 105.8 EUR/ha taken from this same table footnote (c) as representative of a surface water ID. The rationale behind the 2.3 coefficient is that, as a rule of thumb, more powerful pumps are required in groundwater IDs compared to surface water IDs; this has a direct effect on the capacity factor charge.

Table 6 is a compilation of estimated decreases in crop yield due to APV shed shading compared to full-sunlight cultivation. In Table 7, values are five-year (2014-2018) averages calculated from official data of Spain Department of Agriculture [16] compiles crop yields $(\mathrm{kg} / \mathrm{ha})$ and prices $(\mathrm{EUR} / \mathrm{t})$ under full sunlight.

Table 6. Crop yield variation under APV partial shading with respect to full sunlight.

\begin{tabular}{|c|c|c|c|}
\hline & $\begin{array}{c}\text { Crop Yield Variation under Shading }{ }^{(a)}, \text { High } \\
\text { Crop-Yield Penalty } \\
(\%)\end{array}$ & Source $^{(b)}$ & $\begin{array}{c}\text { Crop Yield Variation under Shading }{ }^{(c)} \text {, Low } \\
\text { Crop-Yield Penalty } \\
(\%)\end{array}$ \\
\hline Canola & -20 & [44] & -5 \\
\hline Carrot & -10 & [45] & +5 \\
\hline Maize & -7 & [46] & +8 \\
\hline Faba bean & 0 & [47] & +15 \\
\hline Melon & -17 & [48] & -2 \\
\hline Onion & -6 & [49] & +9 \\
\hline Pea & -15 & [50] & 0 \\
\hline Potato & -23 & [15] & -8 \\
\hline Tomato & -5 & [32] & +10 \\
\hline
\end{tabular}

(a) Rounded to the closest integer. ${ }^{\text {(b) }}$ See Appendix E for details on the uncertainty factors applied. ${ }^{(c)}$ Assumption: $\Delta+15 \%$ over the values in the second column. 
Table 7. Crop revenues under full sunlight conditions.

\begin{tabular}{|c|c|c|c|c|c|}
\hline & $\begin{array}{l}\text { Crop Yield } \\
\text { under Full } \\
\text { Sunlight } \\
\text { (t/ha) }\end{array}$ & $\begin{array}{l}\text { Produce Price } \\
\text { Paid to the } \\
\text { Farmer } \\
\text { (EUR/t) }\end{array}$ & $\begin{array}{c}\text { Farmer Income } \\
\text { from Produce Sale } \\
\text { under Full Sunlight } \\
\text { (EUR/ha) }\end{array}$ & $\begin{array}{l}\text { EU-CAP Direct } \\
\text { Payment to } \\
\text { the Farmer } \\
\left(\text { EUR/ha) }{ }^{(b)}\right.\end{array}$ & $\begin{array}{c}\text { Total Income } \\
\text { under Full } \\
\text { Sunlight } \\
\text { (EUR/ha) }\end{array}$ \\
\hline Canola & 3.10 & 326.9 & 1013 & 35 & 1048 \\
\hline Carrot & 49.22 & 303.4 & 14,933 & NA & 14,933 \\
\hline Forage maize & 59.37 & 41.3 & 2452 & NA & 2452 \\
\hline Dry faba bean & 1.79 & 223.6 & 400 & 45 & 445 \\
\hline Melon & 34.60 & 337.7 & 11,684 & NA & 11,684 \\
\hline Onion & 44.74 & 211.4 & 9458 & NA & 9458 \\
\hline Dry pea & 1.79 & 220.6 & 395 & 45 & 440 \\
\hline Potato & 30.98 & 246.2 & 7627 & NA & 7627 \\
\hline Processing tomato & 85.00 & 72.5 & 6162 & 200 & 6362 \\
\hline
\end{tabular}

(a) Values calculated as 5-year (2014-2018) averages from [16]. ${ }^{(b)}$ NA: Not applicable.

\section{Results}

A well-established metric to assess the performance of dual-land use systems like agroforestry [51] and also APV, is the land equivalent ratio (LER). However, the LER exclusively accounts system revenues and not the expenditure. On the other hand, the benchmark yardstick for energy generation systems, the levelized cost of electricity (LCoE), computes cost relative to electricity yield, but does not incorporate the crop production activity. Here, the indicator wherethrough profitability was evaluated was the internal rate of return (IRR). Once income and expenditure from both agricultural and energy generation activity were accounted, their aggregation to obtain the IRR was straightforward.

Figure 3 shows the annual specific yield of $1628 \mathrm{kWh} / \mathrm{kWp}$ predicted by the PV simulator for the southwest-oriented APV shed. This value was introduced in Table 8 to compute annual PV income throughout the foreseen lifespan. Likewise, the annual specific yield was introduced in Table A3 to compute the annual PV OpEx. After the entire flow of APV income and expenditure was computed, the IRR was calculated for both early-potato and processing-tomato rotation. The same procedure was followed with the annual specific yield of $1786 \mathrm{kWh} / \mathrm{kWp}$ predicted by the SISIFO PV simulator for the south-oriented APV shed.

Unlike Beck et al. [20], we did not find substantial differences between the two orientations. A mean shade factor of $30.6 \%$ was calculated for due south orientation (Figure A3), while the counterpart for due SW was of $29.2 \%$ (Figure A4). The small difference between both values prevented from matching orientation and shade-induced crop yield penalty. Therefore, we determined that in our case-study APV shed orientation only affects electricity production. With the dichotomist sources of variation considered, namely, crop rotation (potato/tomato), source of irrigation water (surface/underground), level of shadeinduced crop yield penalty (low/high) and APV shed orientation (SW/S), the number of combinations analyzed was of $2^{4}$.

The formula for the IRR is given by (Equation (1)):

$$
0=\sum_{\mathrm{t}=1}^{26} \frac{\mathrm{C}_{\mathrm{t}}}{(1+\mathrm{IRR})^{\mathrm{t}}}-\text { CapEx }
$$

where $C_{t}=$ net cash flow during the year $t$ (calculated as the sum of annual income from electricity sale-Table 8 plus annual income from the sale of agricultural produce harvested, with subtraction of annual PV-OpEx-Table A3 and annual crop production cost; for the early-potato rotation, annual agricultural flow is constant throughout the 25-year lifespan, due to rotation symmetry, whereas in the case of the processing-tomato rotation, the annual agricultural flows vary according to the pattern shown in Table A1); CapEx = total initial investment cost (calculated as 562770 EUR/ha in Table A2 multiplied by 22.8 ha, giving $12,831,156$ EUR). 


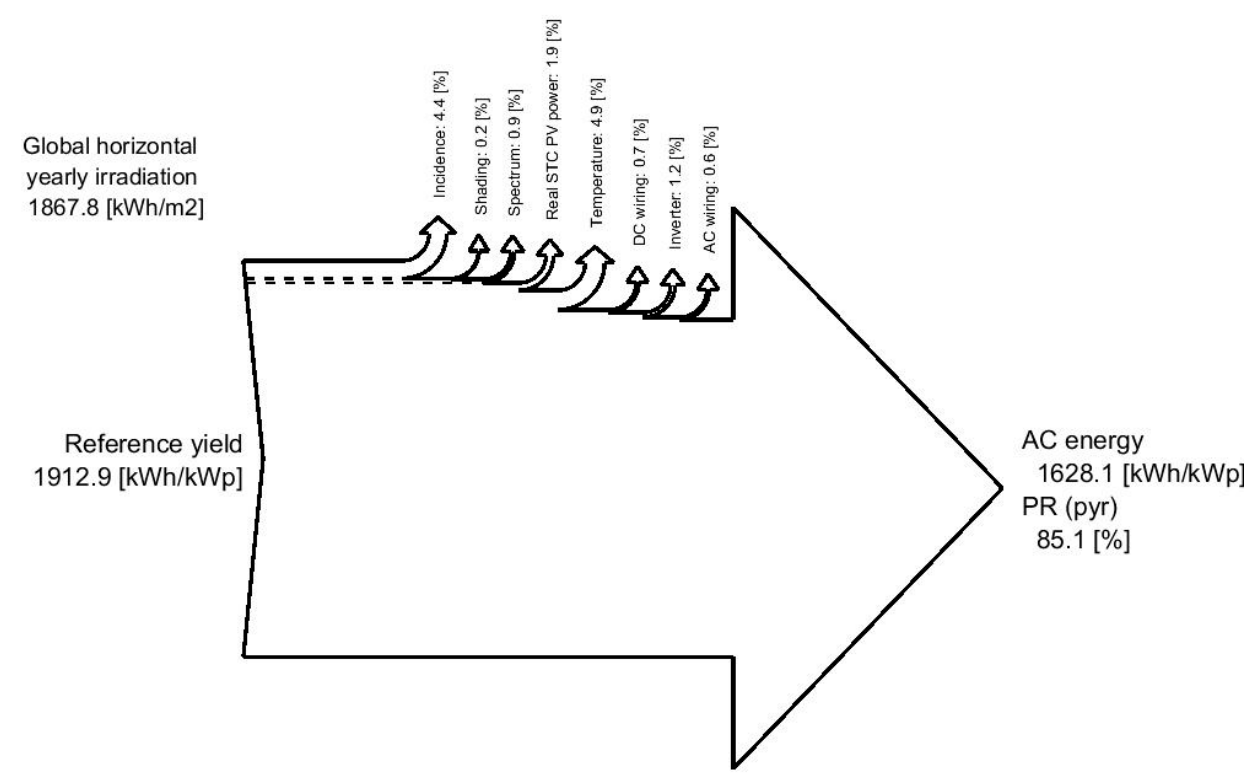

Figure 3. Annual AC energy output as predicted by PV simulator SISIFO [23] for the southwestoriented APV system in Brenes, Seville, Spain.

Table 8. Annual PV income for 24 ha and due SW orientation, assuming a 5\% loss as to PV productive land, due to plot dead corners (PV productive land of $22.8 \mathrm{ha}$ ).

\begin{tabular}{|c|c|c|c|c|c|c|c|}
\hline Year & $\begin{array}{l}\text { PV Module } \\
\text { Degrad. } \\
\text { Coeff. }\end{array}$ & $\begin{array}{c}\text { Specific } \\
\text { Yield } \\
(\mathrm{kWh} / \mathrm{kWp})\end{array}$ & $(\mathrm{kWh} / \mathrm{ha})^{(\mathrm{a})}$ & $\underbrace{\text { Yield }}_{\text {Yotal }}$ & (cEUR/kWh) & $\begin{array}{c}\text { Energy Sale } \\
\text { Income } \\
\text { (EUR) }\end{array}$ & $\begin{array}{c}\text { Total PV } \\
\text { Income } \\
\text { (EUR) }\end{array}$ \\
\hline 1 & & 0 & 0 & 0 & & 0 & 0 \\
\hline 2 & 1 & 1628 & 904,354 & $20,619,271$ & 4.502 & 928,280 & 928,280 \\
\hline 3 & 1 & 1628 & 904,354 & $20,619,271$ & 4.502 & 928,280 & 928,280 \\
\hline 4 & 1 & 1628 & 904,354 & $20,619,271$ & 4.502 & 928,280 & 928,280 \\
\hline 5 & 1 & 1628 & 904,354 & $20,619,271$ & 4.502 & 928,280 & 928,280 \\
\hline 6 & 1 & 1628 & 904,354 & $20,619,271$ & 4.502 & 928,280 & 928,280 \\
\hline 7 & 1 & 1628 & 904,354 & $20,619,271$ & 4.502 & 928,280 & 928,280 \\
\hline 8 & 1 & 1628 & 904,354 & $20,619,271$ & 4.502 & 928,280 & 928,280 \\
\hline 9 & 1 & 1628 & 904,354 & $20,619,271$ & 4.502 & 928,280 & 928,280 \\
\hline 10 & 1 & 1628 & 904,354 & $20,619,271$ & 4.502 & 928,280 & 928,280 \\
\hline 11 & 1 & 1628 & 904,354 & $20,619,271$ & 4.277 & 881,886 & 881,886 \\
\hline 12 & 0.995 & 1620 & 899,832 & $20,516,175$ & 4.277 & 877,477 & 877,477 \\
\hline 13 & 0.990 & 1612 & 895,310 & $20,413,078$ & 4.277 & 873,067 & 873,067 \\
\hline 14 & 0.985 & 1604 & 890,789 & $20,309,982$ & 4.277 & 868,658 & 910,861 \\
\hline 15 & 0.980 & 1595 & 886,267 & $20,206,886$ & 4.277 & 864,249 & 864,249 \\
\hline 16 & 0.975 & 1587 & 881,745 & $20,103,789$ & 4.277 & 859,839 & 859,839 \\
\hline 17 & 0.970 & 1579 & 877,223 & $20,000,693$ & 4.277 & 855,430 & 855,430 \\
\hline 18 & 0.965 & 1571 & 872,702 & $19,897,597$ & 4.277 & 851,020 & 851,020 \\
\hline 19 & 0.960 & 1563 & 868,180 & $19,794,500$ & 4.052 & 802,073 & 802,073 \\
\hline 20 & 0.955 & 1555 & 863,658 & $19,691,404$ & 4.052 & 797,896 & 797,896 \\
\hline 21 & 0.950 & 1547 & 859,136 & $19,588,308$ & 4.052 & 793,718 & 793,718 \\
\hline 22 & 0.945 & 1538 & 854,615 & $19,485,211$ & 4.052 & 789,541 & 789,541 \\
\hline 23 & 0.940 & 1530 & 850,093 & $19,382,115$ & 4.052 & 785,363 & 785,363 \\
\hline 24 & 0.935 & 1522 & 845,571 & $19,279,019$ & 4.052 & 781,186 & 781,186 \\
\hline 25 & 0.930 & 1514 & 841,049 & $19,175,922$ & 4.052 & 777,008 & 777,008 \\
\hline 26 & 0.925 & 1506 & 836,527 & $19,072,826$ & 4.052 & 772,831 & 772,831 \\
\hline
\end{tabular}

(a) $(x \mathrm{kWh} / \mathrm{kWp}) \cdot(555.5 \mathrm{kWp} / \mathrm{ha})=y \mathrm{kWh} / \mathrm{ha}^{\text {(b) }} 0.95 .24 \mathrm{ha}=22.8 \mathrm{ha} ;(y \mathrm{kWh} / \mathrm{ha}) \cdot(22.8 \mathrm{ha})=z \mathrm{kWh}$. (c) Values in this column are equal to values in the adjacent-left column except for the due year of inverters replacement (year 14), where an income of $10 \%$ of inverter purchase price $(18,505 \mathrm{EUR} / \mathrm{ha}$, Table A2) is added in concept of old inverters residual value. Hence, the income added in the year 14 is of: $0.1 \cdot 18,505 \cdot 22.8=42,191 \mathrm{EUR}$

Since the IRR is not explicit in Equation (1), it has to be solved by an iterative method, like the ad hoc function of Microsoft Excel®. Table 9 is a compilation of the IRR for each of the $2^{4}$ combinations, wherein the minimum and maximum IRR are highlighted. 
Table 9. Internal rate of return for the 16 combinations generated.

\begin{tabular}{llcccc}
\hline & & \multicolumn{4}{c}{ IRR (\%) } \\
\cline { 3 - 6 } & & \multicolumn{2}{c}{ Due-Southwest Orientation } & \multicolumn{3}{c}{ Due-South Orientation } \\
\cline { 3 - 6 } & & $\begin{array}{c}\text { Low Shade-InduceD } \\
\text { Crop Yield Penalty }\end{array}$ & $\begin{array}{c}\text { High Shade-InduceD } \\
\text { Crop Yield Penalty }\end{array}$ & $\begin{array}{c}\text { Low Shade-InduceD } \\
\text { Crop Yield Penalty }\end{array}$ & $\begin{array}{c}\text { High Shade-InduceD } \\
\text { Crop Yield Penalty }\end{array}$ \\
\hline \multirow{2}{*}{ Potato rotation } & Surface Water & 4.1 & 3.9 & 5.1 & 4.8 \\
& Ground Water & 4.0 & 3.8 & 5.0 & 4.8 \\
\hline \multirow{2}{*}{ Tomato rotation } & Surface Water & 4.7 & 4.3 & 5.6 & 5.2 \\
& Ground Water & 4.6 & 4.2 & 5.6 & 5.2 \\
\hline
\end{tabular}

To elucidate the profitability associated to the foregoing IRRs, they were confronted with the private investor expected remuneration or annual cost of equity $\left(\mathrm{r}_{\mathrm{e}}\right)$. According to Guaita-Pradas and Blasco-Ruiz [52], the cost of equity can be estimated through the capital asset pricing model, (Equation (2)):

$$
r_{e}=r_{f}+\left(r_{m}-r_{f}\right)
$$

where $r_{e}=$ annual cost of equity, i.e.,demanded rate of return on equity; $r_{f}=$ annual risk-free rate of return; $\mathrm{r}_{\mathrm{m}}=$ annual stock-exchange market rate of return; $\beta=$ coefficient that reflects the sensitivity of the sector to market fluctuations.

A good representative for $r_{f}$ in Spain is the interest rate of the 30-year maturity Public Treasury bonds, $1.31 \%$ [53]. Current market profitability, $\mathrm{r}_{\mathrm{m}}$, is of $4.5 \%$ [54]. In strict sense, in our case $\beta$ would be somehow compounded, since the project economic activity sector is not only electric generation but also agricultural production. For the sake of simplicity, we took a PV $\beta$ of 1.10 [55]. Substituting in (Equation (2)):

$$
\mathrm{r}_{\mathrm{e}}=0.0131+(0.045-0.0131) \cdot 1.10=0.04819
$$

Therefore, the threshold of profitability is $4.8 \%$. The IRRs compiled in Table 9 indicate that some combinations would be profitable from the perspective of a private investor, whereas others would be not.

\section{Discussion}

Following the mainstream APV philosophy of prioritizing agricultural over power production and based on Beck et al. [20] conclusion, we initially performed calculations for a SW-oriented APV shed. Finally, a comparative shaded-fraction analysis between southwest and south orientation was undertaken. The small difference found (abovementioned values of $29.2 \%$ and $30.6 \%$ ), together with the shape of histograms Figures A3 and A4 suggest little difference between both orientations. Perhaps the subtle difference in ground radiation uniformity in our case was due to the TMY data used. Edge effects could also play a role. This issue deserves more attention and should be further analyzed in a future work.

The result obtained for the early-potato rotation when the APV shed is oriented due Southwest is in line with Trommsdorff [56], who, for organic potatoes cultivated beneath the APV shed described by Schindele et al. [8], obtained an IRR 1.6\% lower than WACC. In a broader sense, López Prol et al. [43] wondered if renewable energy generators like PV would ever be competitive considering the faster decline of the wholesale market price compared to the LCoE. From the inception of our study, it was envisaged that a negative factor for APV system profitability would be the high CapEx compared to conventional ground-mounted PV power plants. To restrain APV system CapEx, fixed-tilt PV modules were selected instead of single-axis trackers, which are 7\% more expensive in average [57]. Here, the reason to select fixed-tilt PV generator was three-fold: First, to restrain system cost; second, to utilize the substructure described by Schindele et al. [8], which is of known cost; and third, to cast less shading on the understorey crop canopy. With regard to the latter, in an early stage a set of simulations was performed with the dual-use shading analysis tool, an on-line simulator promoted by the Massachusetts government to analyze the technical 
viability of APV layouts. Results indicated that single-axis tracking casted more shading, in $\mathrm{w} \%$ per square meter than fixed-tilt. On the other hand, Amaducci et al. [58] concluded that reduction of global radiation beneath their APV shed was more affected by PV module array GCR than by tilt angle management (fixed tilt/sun-tracking).

In the case that in one of the 6 ha APV plots there existed an authorized underground water well equipped with a submersible pump, a reservoir to store the water abstracted by the well pump and a horizontal-axis pump to pressurize the whole 24 ha farmer irrigation network, the following management strategy could be analyzed: During PV productive hours, a small fraction of the energy produced would be self-consumed by the well pump to replenish the reservoir. To irrigate, i.e., to pressurize the irrigation network preferably during nocturnal hours, energy would be consumed from the grid, through the same HV power transmission line wherethrough PV production is injected. The energy consumed would be registered, for billing purposes, by a bi-directional metering gauge. This management strategy would remove the cost of water delivery charged by the irrigation district. Concurrently, the income from the sale of electricity would be diminished in the amount of the energy self-consumed-and therefore, not sold-by the well pump. Likewise, the farmer would incur in the cost of the nocturnal energy consumed from the grid by the irrigation pump. According to IDAE [59], average installed power pump for pressurized irrigation in Spain is of $2 \mathrm{~kW} /$ ha. For a flat topography like the area of study, assuming low pressure drip irrigation and for moderate water depth in the well, the share of installed power could be e.g., $70 \%$ for the submersible well pump and $30 \%$ for the irrigation pump (the well pump share would increase with increasing depth). Therefore, this results in $0.32 \mathrm{~kW} / \mathrm{ha}=0.6 \mathrm{~kW} / \mathrm{ha}$ and $0.6 \mathrm{~kW} / \mathrm{ha} 24 \mathrm{ha}=14.4 \mathrm{~kW}$. This is significantly smaller than $450 \mathrm{~kW}$, the minimum contracted power to benefit from the cheapest nocturnal electricity period of the Spanish tariff 6.1.

With regard to the possibility of reducing the $5 \mathrm{~m}$ clearance height of APV shed substructure and accordingly save in system CapEx, the following has to be considered: In our study, one head of rotation was first-early potato, planted in late December-January and harvested in late May-early June. In Spain, this type of potato is not harvested with the bulky and tall potato harvester, but with much smaller and shorter machines, namely, potato lifters and windrowers. These machines just dig-up and expose the tubers so that they can be afterwards hand-picked by manual workers. The reason to discard the potato harvester is to preserve tuber quality, since hand-picking is less aggressive. In other parts of Spain, where half-season potatoes are grown, the tubers spend more time within the ground, resulting in a thicker skin that withstands better the abrasions and impacts that occur inside potato harvester. Attending to the potato harvesting machinery used in the area, one could think of saving in substructure height, at least in the case of the earlypotato rotation. However, a two-fold reason dissuade from this: First, canola and faba bean, two of the potato "partners" in the eponymous rotation, are harvested with the bulky combine harvester. Second, the main interest of a high substructure is not only to allow agricultural machinery work beneath, but to provide homogenous light distribution for the crop, casting shade of lower intensity. Analogous considerations apply for the processing-tomato rotation, whereinto processing tomato is harvested with a bulky-tall machine, similar in dimensions to both the potato and combine harvesters.

Among the circumstances that would yield lower IRR are: (i) APV plots remoteness from the grid-connection switchyard (distance higher than the $1 \mathrm{~km}$ assumed in Figure 1; (ii) re-activation of Spanish Law 15/2012, under which electricity generators must satisfy a tax of $7 \%$ on the value of the energy injected to the grid -this law was challenged before the Constitutional Court of Spain and the final judgment is pending [60].

Among the circumstances that could render higher IRR are: (i) Higher electricity yield due to favorable microclimate condition. Thus, the SISIFO PV simulator used here is not APV-specific but computes yield from site TMY climate data. Cooler temperatures on the back side of the modules, induced by the irrigated understory crop, would improve PV performance, especially in the summer months. (ii) Modification of the PV system electrical 
design: considering that while the peak power $(153.1 \mathrm{kWp})$ to nominal power $(150 \mathrm{kWp})$ ratio is of approximately $1.02 \mathrm{Wp} / \mathrm{Wn}$; stronger oversizing of the $\mathrm{PV}$ array with respect to inverter is recommended [61].

Here, only the quantitative effect of shading on produce yield ( $t / h a)$ was considered. More research is needed to investigate the effect of APV shading on produce quality that ultimately affects revenues or even could be a limiting factor for the spread of APV. Nishizawa et al. [62] concluded that severe levels of shading negatively affected melon fruit firmness. Hernández et al. [32] measured not only higher concentration of lycopene, but also lower concentration of vitamin $C$ and phenolic compounds, in tomatoes grown under partial shade compared to the full-sunlight counterpart.

In the authors' opinion, the lack of profitability in some of the combinations of the case-study analyzed herein does not tarnish the potential profitability of APV systems. Higher IRR is envisaged for specialty crops, thanks to extended synergies between the food generator-agricultural crop-and energy generator-PV modules. Savings in fruit orchard hail and bird netting allowed by APV sheds paddle in this direction [63]. Likewise, the utilization of semi-transparent PV modules could increase crop intercepted light without the need for the expensive $5 \mathrm{~m}$ ground-clearance substructure that supports conventional opaque PV modules. The fragility of specialties such as raspberry, blackberry and blueberry advises against their mechanized harvesting, contributing to the technical viability of cost-effective limited-height sheds and the subsequent increased profitability of APV systems.

\section{Conclusions}

In correspondence with objectives (1) and (2) indicated in Section 1, the following conclusions can be drawn:

1. two crop rotations, one of them headed by early-potato partnered with canola, faba bean, forage-maize and onion, and the other one headed by processing-tomato partnered with onion, dry-pea, carrot and melon were designed;

2. the stream of expenditure and revenues for both agricultural and electric energy production was determined for a lifespan of 25 years. The internal rates of return obtained ranged from a minimum of $3.8 \%$ for the combination of southwest orientation, early-potato rotation, groundwater and high shade-induced crop-yield penalty to a maximum of $5.6 \%$ for the combination of South orientation, processing-tomato rotation, surface water and low shade-induced crop-yield penalty.

Author Contributions: Conceptualization, M.A.M.-G., G.P.M. and M.C.A.-G.; methodology, G.P.M., M.A.M.-G. and M.C.A.-G.; validation, G.P.M., M.A.M.-G., M.C.A.-G. and L.H.-C.; formal analysis, G.P.M., L.H.-C. and M.C.A.-G.; investigation, G.P.M., M.A.M.-G., M.C.A.-G. and L.H.-C.; data curation, G.P.M.; writing —original draft preparation, G.P.M., M.A.M.-G. and M.C.A.-G.; writing—review and editing, G.P.M., M.A.M.-G., M.C.A.-G. and L.H.-C. All authors have read and agreed to the published version of the manuscript.

Funding: This research received no external funding.

Institutional Review Board Statement: Not applicable.

Informed Consent Statement: Not applicable.

Data Availability Statement: The data presented in this study are available on request from the corresponding author.

Acknowledgments: The authors wish to acknowledge the reviewers for their valuable comments.

Conflicts of Interest: The authors declare no conflict of interest. 


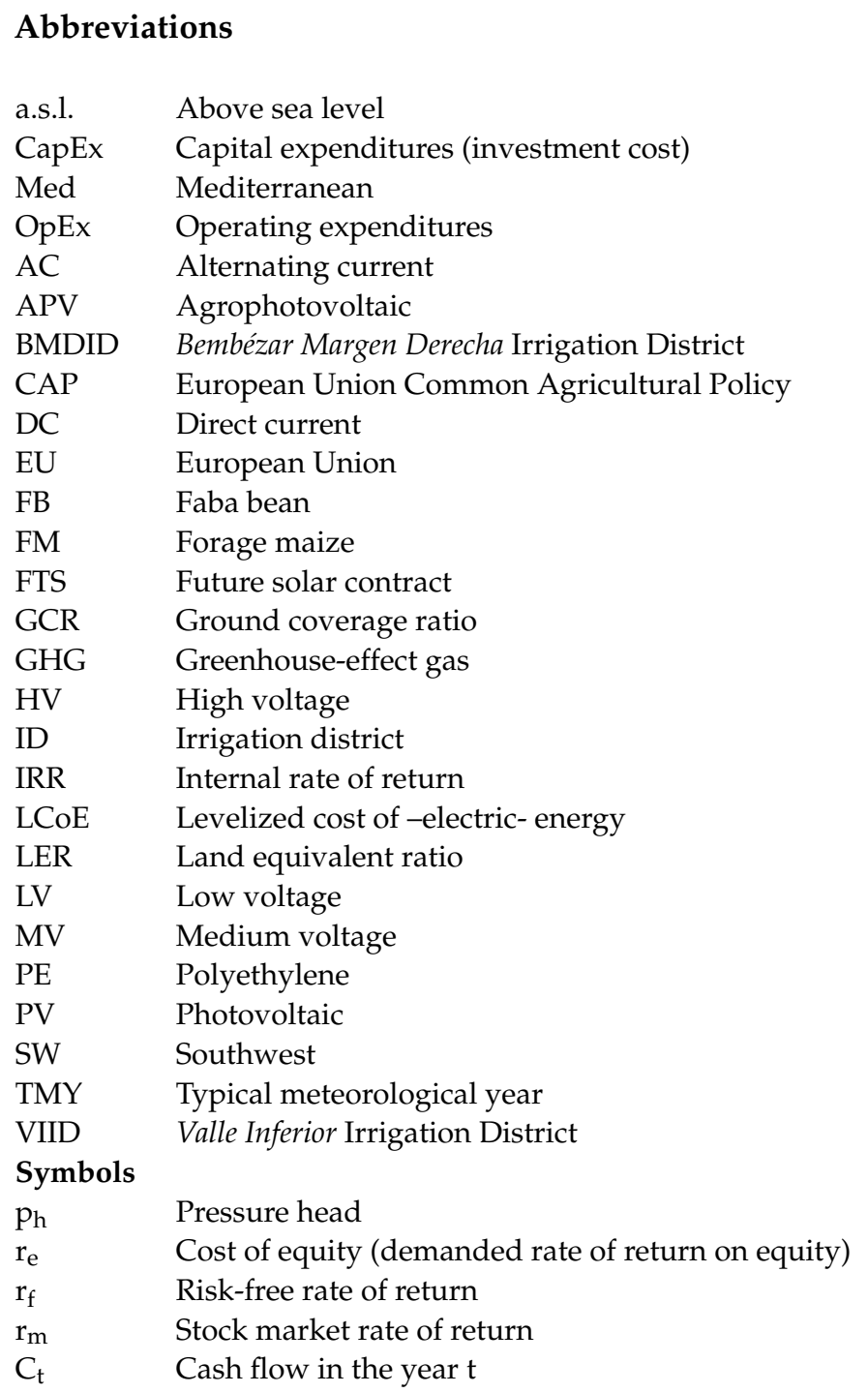

\section{Appendix A}

Comparison between due south and due southwest orientation of APV shed.

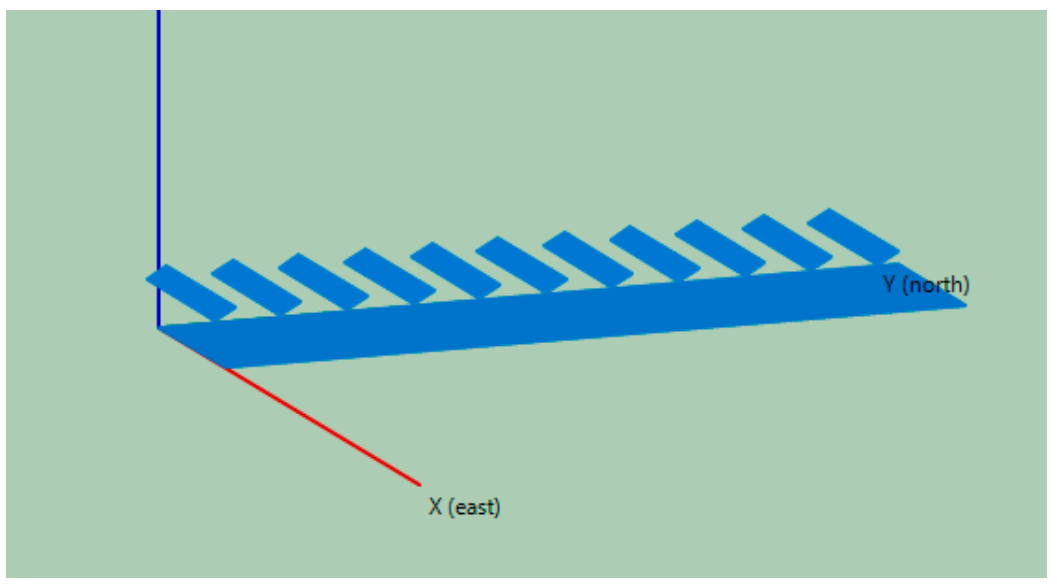

Figure A1. Due south APV shed. Ground area: $26 \mathrm{~m} \times 106 \mathrm{~m}$. Dimensions and number of PV module supporting structures: $26 \mathrm{~m} \times 3.28 \mathrm{~m} \times 11$. Equidistance between supporting structures axes: $9.5 \mathrm{~m}$, as in Figure 2. 


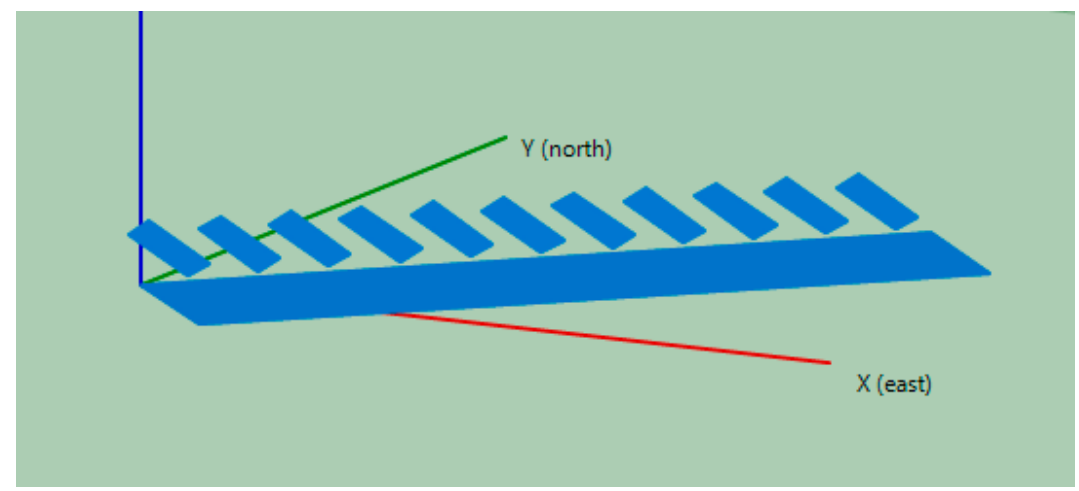

Figure A2. Due southwest APV shed.

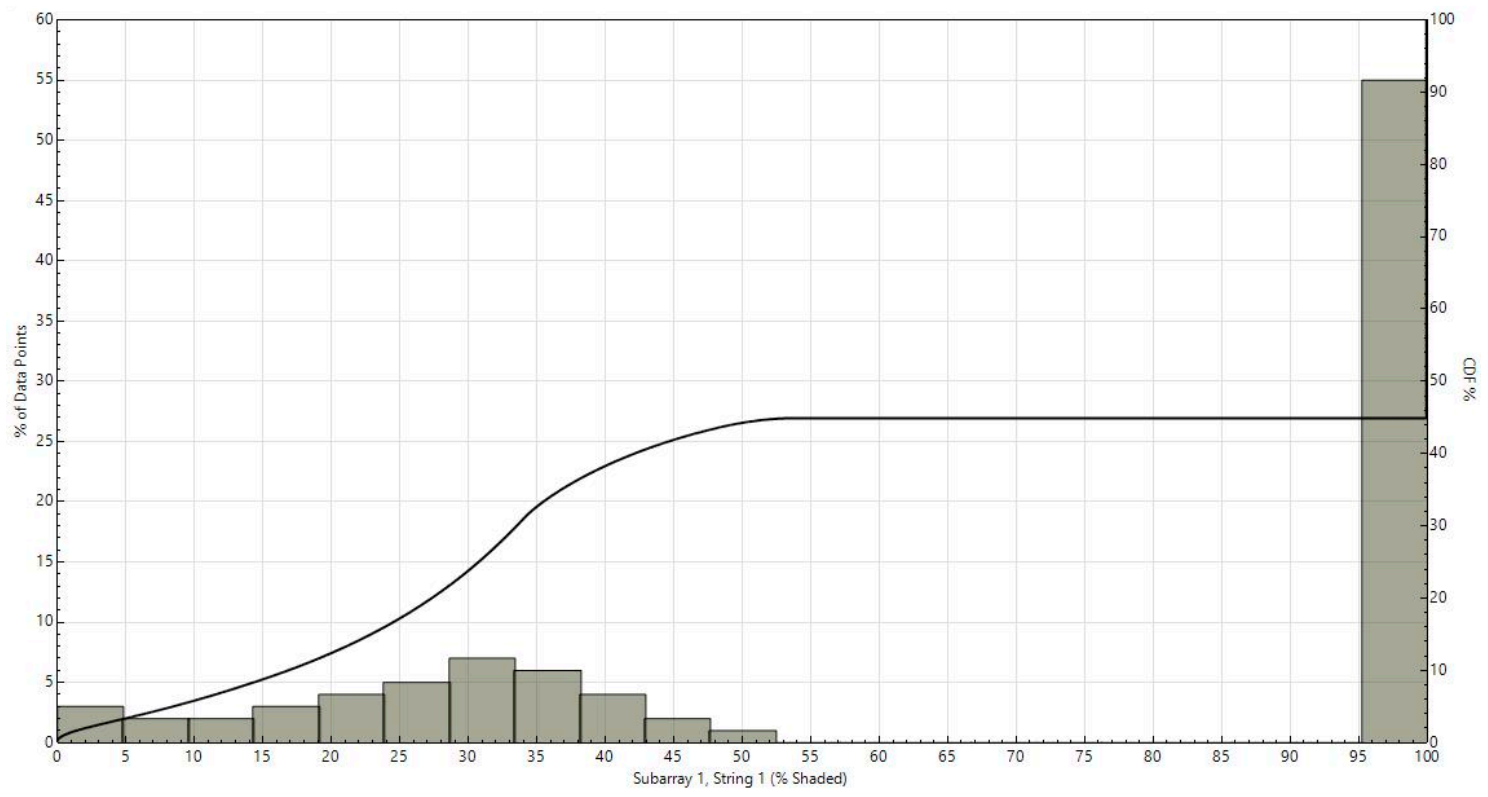

Figure A3. Time series (1 min step) shaded fraction histogram (zero values excluded) for due south orientation.

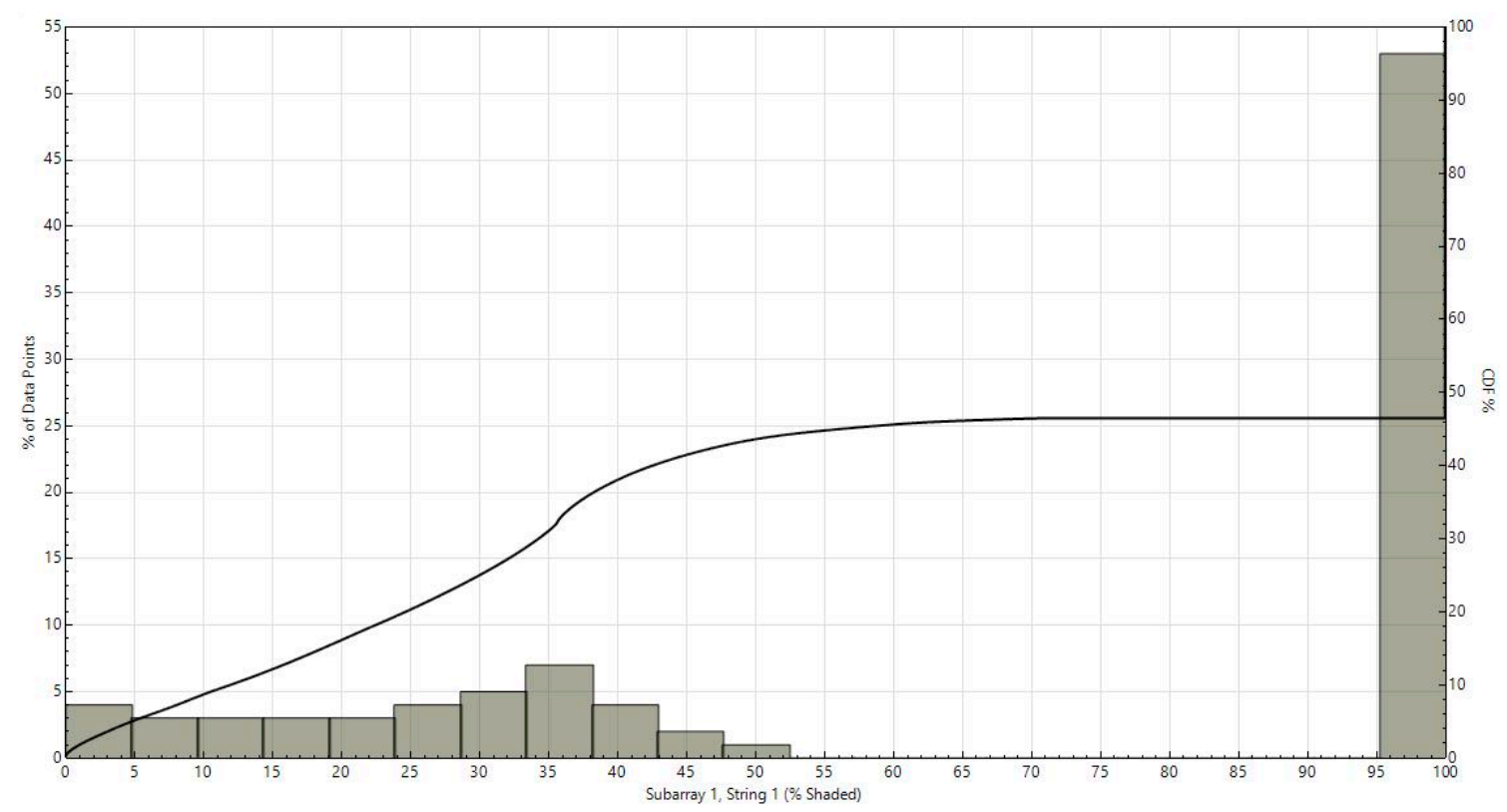

Figure A4. Time series (1 min step) shaded fraction histogram (zero-values excluded) for due southwest orientation. 


\section{Appendix B}

Table A1. Processing-tomato rotation scheduling for 25-year lifespan.

\begin{tabular}{|c|c|c|c|c|}
\hline Year & Plot 1 & Plot 2 & Plot 3 & Plot 4 \\
\hline 2 & Melon & Onion & Carrot & Tomato \\
\hline 3 & Onion & Carrot & Melon & Tomato \\
\hline 4 & Carrot & Melon & Onion & Tomato \\
\hline 5 & Tomato & Onion & Pea & Melon \\
\hline 6 & Tomato & Onion & Onion & Onion \\
\hline 7 & Tomato & Carrot & Carrot & Carrot \\
\hline 8 & Melon & Tomato & Melon & Melon \\
\hline 9 & Carrot & Tomato & Onion & Onion \\
\hline 10 & Melon & Tomato & Carrot & Carrot \\
\hline 11 & Onion & Melon & Tomato & Melon \\
\hline 12 & Pea & Onion & Tomato & Onion \\
\hline 13 & Onion & Carrot & Tomato & Pea \\
\hline 14 & Carrot & Melon & Melon & Tomato \\
\hline 15 & Melon & Onion & Onion & Tomato \\
\hline 16 & Onion & Carrot & Carrot & Tomato \\
\hline 17 & Tomato & Melon & Melon & Melon \\
\hline 18 & Tomato & Onion & Onion & Onion \\
\hline 19 & Tomato & Pea & Carrot & Carrot \\
\hline 20 & Melon & Tomato & Melon & Melon \\
\hline 21 & Onion & Tomato & Onion & Onion \\
\hline 22 & Carrot & Tomato & Pea & Carrot \\
\hline 23 & Melon & Melon & Tomato & Melon \\
\hline 24 & Onion & Onion & Tomato & Onion \\
\hline 25 & Carrot & Carrot & Tomato & Pea \\
\hline 26 & Melon & Melon & Melon & Tomato \\
\hline
\end{tabular}

\section{Appendix C}

Table A2. APV system initial investment cost or capital expenditure, CapEx (the delayed CapEx item of inverters replacement incurred in year 14 is included in Table A3).

\begin{tabular}{|c|c|c|c|c|}
\hline & \multirow{2}{*}{ EUR/unit } & \multirow{2}{*}{$\mathrm{EUR} / \mathrm{kWp}$} & \multirow{2}{*}{ EUR/ha ${ }^{\text {(a) }}$} & \multirow{2}{*}{$\begin{array}{c}\text { No. Units Per ag. } \\
\text { Plot of } 6(5.7) \text { ha }\end{array}$} \\
\hline & & & & \\
\hline (1) PV modules & 60.9 & $210.0^{(b)}$ & 116,655 & $10,919^{\text {(c) }}$ \\
\hline (2) Galvanized steel mounting structure & & $378.6^{(\mathrm{d})}$ & 210,312 & \\
\hline (3) Earthing & & $0.6^{(\mathrm{e})}$ & 333 & \\
\hline (4) Lightning protection system & & & $9000^{(\mathrm{f})}$ & \\
\hline (5) DC switchboards (combiner boxes) & $584.0^{(\mathrm{g})}$ & 3.8 & 2111 & 21 \\
\hline (6) DC cables & & $35.0^{(\mathrm{h})}$ & 19,443 & \\
\hline (7) Inverters & $5100.0^{(i)}$ & $33.3^{(\mathrm{j})}$ & 18,505 & 21 \\
\hline (8) AC low voltage cables & & $18.4^{(\mathrm{e})}$ & 10,221 & \\
\hline (9) LV/MV Transformer & $80,500.0^{(\mathrm{e})}$ & $25.4^{(\mathrm{k})}$ & 14,124 & 1 \\
\hline (10) MV overhead power transmission line & & $1.9^{(1)}$ & 1055 & \\
\hline (11) Monitoring and communications & & $0.9^{(\mathrm{e})}$ & 500 & \\
\hline (12) Security & & $2.1^{(\mathrm{e})}$ & 1167 & \\
\hline (13) Installation works & & & $132,490^{(\mathrm{m})}$ & \\
\hline (14) Subtotal $1\{=\Sigma(1) \ldots$ (13) $\}$ & & & 535,916 & \\
\hline (15) Administration costs $(1 \%)$ & & & 5359 & \\
\hline (16) Designer and construction manager fees (4\%) & & & 21,437 & \\
\hline (17) Subtotal $2\{=(14)+(15)+(16)\}$ & & & 562,712 & \\
\hline (18) Subsoiling & & & $58^{(n)}$ & \\
\hline (19) TOTAL $\{=(17)+(18)\}$ & & & 562,770 & \\
\hline
\end{tabular}

(a) $(x$ EUR $/ \mathrm{kWp}) \cdot(555.5 \mathrm{kWp} / \mathrm{ha})=y$ EUR/ha. ${ }^{(\mathrm{b})}$ [64]. (c) $(528$ modules $/ 153.1 \mathrm{kWp}) \cdot 3166 \mathrm{kWp}=10,919$ modules. ${ }^{\text {(d) }}$ Calclated from

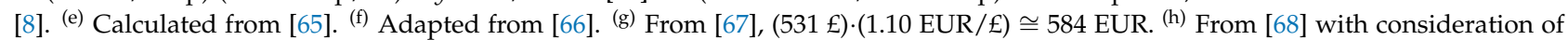
1000 VDC inverter wire section saving. ${ }^{(i)}$ From [69], $\left(0.034\right.$ EUR/W $\left.\mathrm{AC}_{\mathrm{AC}}\right) \cdot\left(150 \mathrm{~kW}_{\mathrm{AC}}\right)=5100 \mathrm{EUR}$. ${ }^{(\mathrm{j})} 5100 \mathrm{EUR} / 153.1 \mathrm{kWp} \cong 33.3 \mathrm{EUR} / \mathrm{kWp}$. (k) $80500 \mathrm{EUR} / 3166 \mathrm{kWp} \cong 25.4 \mathrm{EUR} / \mathrm{kWp}$. ${ }^{(1)}$ Calculated from [70]. ${ }^{(\mathrm{m})}$ Calculated by introducing $155,241 \mathrm{EUR} /$ ha [8] in the following breakdown model: Construction work, $65 \%$ of the installation works cost; electrical installation work, $35 \%$ of the installation works cost; labor share within construction work, $40 \%$; labor share within electrical installation work, $70 \%$; ancillary equipment (cranes, welding machines, tools, etc.) share within construction work, $60 \%$; ancillary equipment share within electrical installation work, 30\%. Price of construction labor in Spain relative to Germany: 54\%; price of electrician labor in Spain relative to Germany: 89\% [71]. ${ }^{(\mathrm{n})}$ [72]. 
Table A3. Twenty-four hectare (22.8 ha effective) due SW-oriented PV system annual operating expenditure, OpEx, plus the delayed CapEx of inverters replacement in the year 14 .

\begin{tabular}{|c|c|c|c|c|c|c|c|}
\hline Year & $\begin{array}{c}\text { Total } \\
\text { Annual Yield (a) } \\
\text { (MWh) }\end{array}$ & $\begin{array}{l}\text { Grid Access } \\
\text { Toll (b) } \\
\text { (EUR) }\end{array}$ & $\begin{array}{l}\text { Brokerage P.W.M. } \\
\text { Agent (c) } \\
\text { (EUR) }\end{array}$ & $\begin{array}{l}\text { Maintenance and } \\
\text { Repair (d) }^{(\text {EUR) }}\end{array}$ & $\begin{array}{c}\text { Insurance and } \\
\text { Video-Surv. }{ }^{(e)} \\
\text { (EUR) }\end{array}$ & $\begin{array}{l}\text { Internet } \\
\text { Fee (f) } \\
\text { (EUR) }\end{array}$ & $\begin{array}{c}\text { TOTAL } \\
\text { (EUR) }\end{array}$ \\
\hline 1 & 0 & 0 & 0 & 0 & 0 & 0 & 0 \\
\hline 2 & 20,619 & 10,310 & 4124 & 26,597 & 22,798 & 10,132 & 73,961 \\
\hline 3 & 20,619 & 10,310 & 4124 & 26,597 & 22,798 & 10,132 & 73,961 \\
\hline 4 & 20,619 & 10,310 & 4124 & 26,597 & 22,798 & 10,132 & 73,961 \\
\hline 5 & 20,619 & 10,310 & 4124 & 26,597 & 22,798 & 10,132 & 73,961 \\
\hline 6 & 20,619 & 10,310 & 4124 & 26,597 & 22,798 & 10,132 & 73,961 \\
\hline 7 & 20,619 & 10,310 & 4124 & 26,597 & 22,798 & 10,132 & 73,961 \\
\hline 8 & 20,619 & 10,310 & 4124 & 26,597 & 22,798 & 10,132 & 73,961 \\
\hline 9 & 20,619 & 10,310 & 4124 & 26,597 & 22,798 & 10,132 & 73,961 \\
\hline 10 & 20,619 & 10,310 & 4124 & 26,597 & 22,798 & 10,132 & 73,961 \\
\hline 11 & 20,619 & 10,310 & 4124 & 26,597 & 22,798 & 10,132 & 73,961 \\
\hline 12 & 20,516 & 10,258 & 4103 & 26,597 & 22,798 & 10,132 & 73,889 \\
\hline 13 & 20,413 & 10,207 & 4083 & 26,597 & 22,798 & 10,132 & 73,817 \\
\hline 14 & 20,310 & 10,155 & 4062 & 26,597 & 22,798 & 10,132 & $474,562^{(g)}$ \\
\hline 15 & 20,207 & 10,103 & 4041 & 26,597 & 22,798 & 10,132 & 73,672 \\
\hline 16 & 20,104 & 10,052 & 4021 & 26,597 & 22,798 & 10,132 & 73,600 \\
\hline 17 & 20,001 & 10,000 & 4000 & 26,597 & 22,798 & 10,132 & 73,528 \\
\hline 18 & 19,898 & 9949 & 3980 & 26,597 & 22,798 & 10,132 & 73,456 \\
\hline 19 & 19,795 & 9897 & 3959 & 26,597 & 22,798 & 10,132 & 73,384 \\
\hline 20 & 19,691 & 9846 & 2954 & 19,948 & 17,099 & 7599 & 57,445 \\
\hline 21 & 19,588 & 9794 & 2938 & 19,948 & 17,099 & 7599 & 57,378 \\
\hline 22 & 19,485 & 9743 & 2923 & 19,948 & 17,099 & 7599 & 57,311 \\
\hline 23 & 19,382 & 9691 & 2907 & 19,948 & 17,099 & 7599 & 57,244 \\
\hline 24 & 19,279 & 9640 & 2892 & 19,948 & 17,099 & 7599 & 57,177 \\
\hline 25 & 19,176 & 9588 & 2876 & 19,948 & 17,099 & 7599 & 57,110 \\
\hline 26 & 19,073 & 9536 & 2861 & 19,948 & 17,099 & 7599 & 57,043 \\
\hline
\end{tabular}

(a) From Table 8. (b) 0.5 EUR/MWh [73]. (c) p.w.m., power whosale market. Brokerage fee applied: 0.2 EUR/MWh [74], years 2 through 19; years 20 through 26: assumption of $25 \%$ price decrease applied [69], resulting in 0.15 EUR/MWh. (d) Years 2 through 19, $(2.1 \mathrm{EUR} / \mathrm{kWp}) \cdot(555.5 \mathrm{kWp} / \mathrm{ha}) \cdot(22.8 \mathrm{ha})=26,597 \mathrm{EUR}$; years 20 through 26 : assumption of $25 \%$ price decrease applied [32], $0.75 \times 26,597=19,948$ EUR. (e) Years 2 through 19, $(1.8 \mathrm{EUR} / \mathrm{kWp}) \cdot(555.5 \mathrm{kWp} / \mathrm{ha}) \cdot(22.8 \mathrm{ha})=22,798 \mathrm{EUR}$; years 20 through 26: assumption of $25 \%$ price decrease applied [32], $0.75 \times 22,798=17,099$ EUR. ${ }^{(\mathrm{f})}$ Years 2 through 19, $(0.8 \mathrm{EUR} / \mathrm{kWp}) \cdot(555.5 \mathrm{kWp} / \mathrm{ha}) \cdot(22.8 \mathrm{ha})=10,132 \mathrm{EUR}$; years 20 through 26 : assumption of $25 \%$ price decrease applied [32], $0.75 \times 10,132=7599$ EUR. (g) Inverter's replacement cost included $(0.95 \times 18,505 \mathrm{EUR} / \mathrm{ha} \times 22.8 \mathrm{ha}=400,818 \mathrm{EUR}$; a $\%$ price decrease is assumed with respect to the year zero; $18505 \mathrm{EUR} / \mathrm{ha}$ taken from Table A2). 


\section{Appendix D}

Table A4. Annual production costs for the 9 crops under full sunlight. Values adapted from [75,76].

\begin{tabular}{|c|c|c|c|c|c|c|c|c|c|}
\hline Costs in EUR/ha & Canola & Carrot & Forage Maize & Dry Faba Bean & Melon & Onion & Dry Pea & Early Potato & ProCessing Tomato \\
\hline Seed & 60 & 3900 & 170 & 60 & 3000 & 3925 & 55 & 1400 & 820 \\
\hline Fertilizer & 205 & 860 & 610 & 10 & 800 & 750 & 10 & 600 & 590 \\
\hline Plant Protection products & 115 & 650 & 50 & 60 & 505 & 230 & 60 & 250 & 510 \\
\hline Externalized works (mechanized harvest, etc.) & 67 & 1390 & 85 & 55 & 80 & 75 & 55 & 110 & 850 \\
\hline Tractor fuel & 60 & 420 & 120 & 60 & 330 & 180 & 60 & 105 & 110 \\
\hline Tractor \& mach. Repair \& Maint. & 45 & 230 & 106 & 40 & 110 & 105 & 40 & 80 & 80 \\
\hline Tractor \& mach. Shed costs & 30 & 60 & 45 & 30 & 60 & 60 & 30 & 55 & 60 \\
\hline Amortization of tractor \& mach. & 20 & 170 & 105 & 17 & 150 & 145 & 17 & 120 & 140 \\
\hline Soc. Sec. contrib.for hired labor $(25 \%)$ & 0 & 0 & 0 & 0 & 281 & 259 & 0 & 225 & 0 \\
\hline Own labor & 65 & 480 & 200 & 50 & 500 & 350 & 50 & 290 & 580 \\
\hline Soc. Sec. contrib.for own labor ( $25 \%)$ & 16 & 120 & 50 & 13 & 125 & 88 & 13 & 73 & 145 \\
\hline Insurances (crop, tractor) & 15 & 57 & 15 & 15 & 100 & 100 & 15 & 57 & 100 \\
\hline Land property tax & 70 & 70 & $35^{(\mathrm{d})}$ & $35^{(d)}$ & 70 & 70 & 70 & 70 & 70 \\
\hline Irrigation total cost & 130 & 226 & $165^{(d)}$ & $79^{(d)}$ & 192 & 224 & 132 & 186 & 205 \\
\hline Subtotal & 898 & 8633 & 1756 & 524 & & & & & 4260 \\
\hline Working capital interest ( $4 \%)$ & 36 & 345 & 70 & 21 & & & & & 170 \\
\hline Total & 934 & 8978 & 1826 & 544 & 7725 & 7899 & 631 & 4701 & 4430 \\
\hline
\end{tabular}

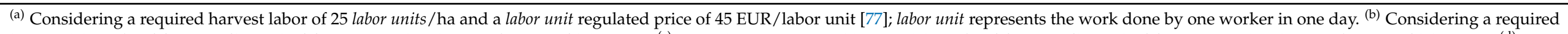

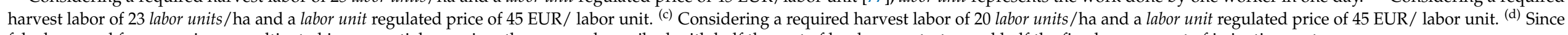
faba bean and forage maize are cultivated in sequential cropping, they are each ascribed with half the cost of land-property-tax and half the fixed component of irrigation cost. 


\section{Appendix E}

Uncertainty factors applied on literature references to obtain percentage yield variation under shading for each crop (high crop yield penalty).

\section{Appendix E.1. Canola}

We took -20\% yield value straightforwardly from Figure 1 [44], as the average of their experiments shading at flowering (2011) and shading at pod filling (2011). We disregarded yield value of shading at flowering (2010) because that year was extremely dry and we are analyzing irrigation farming.

\section{Appendix E.2. Carrot}

We pay attention to the marketable yield column of Table 2 [45]. From the different shading nets listed there, we select white polyethylene (PE) as the closer to our APV-shed configuration (at first glance, one could think that due to monofaciality of our PV modules, black PE would be more similar, but the shading intensity decrease due to modules height plays a role). With respect to no-shade, the variation is of $9.6 \%$, which we rounded to $10 \%$.

\section{Appendix E.3. Maize}

We paid attention to Table 2 [46], biomass of corn stover and Table 3, grain yield. To be conservative, for both tables we focused on the higher PV GCR. We took data from both tables because forage maize crop harvest is a mix of chopped stover, ears and grains. From Table 2 [46], we obtained $-3 \%$ under shading, whereas from Table 3 [46], we obtained $-3.6 \%$. The average of both values is $3.3 \%$. To be conservative, we applied an uncertainty factor of 2, which multiplied by 3.3 equals $6.6 \%$, and finally, rounded to $7 \%$. The reason underlying the uncertainty factor of 2 is that Sekiyama and Nagashima [46] experiments were conducted at latitude $35^{\circ} \mathrm{N}$, while our latitude is higher $\left(37^{\circ} \mathrm{N}\right)$.

\section{Appendix E.4. Faba Bean}

Table 2 [47] shows higher yield under shading than under full sunlight. To be conservative, we assume zero variation with respect to full sunlight.

\section{Appendix E.5. Melon}

In Figure A3 [48], we took marketable yields corresponding to control (full sunlight) and aluminet shading net, which to our understanding is more similar to our APV shading than the other two types of shading net categorized in Figure 3 [48]. The difference between them is approximately $8.4 \mathrm{t} / \mathrm{ha}$, which divided by the control equals $16.5 \%$, which we rounded to $17 \%$.

\section{Appendix E.6. Onion}

From Table 7 [49], we calculated an average yield variation of $2.3 \%$ between full sunlight and shading conditions. Then, we applied an uncertainty factor of 2.5 , for a three-fold reason: First, the latitude of Khan et al. [49] experiment was tropical, unlike ours; second, their shade was not generated by an inert artificial screen, but by a plant canopy which entails a competition not only for sunlight, but also for soil nutrients. In third place, the onion yield ( $t / h a$ ) reported [49] are much lower than the common in our area, most probably because spacing between plants was rather large. Finally, we calculated $2.3 \% \cdot 2.5=5.8 \%$, which we rounded to $6 \%$.

\section{Appendix E.7. Pea}

In Table 2 [50], we took the yield values of lighter shading — one layer of screen—which, to our understanding, reflects better the light conditions under our APV shed and compare them to the no-shade conditions. For the year 1973, we obtained $19.4 \%$, whereas for 1974 we obtained $10.5 \%$. The average of both is approximately $14.9 \%$, which we rounded to $15 \%$. 


\section{Appendix E.8. Potato}

We took years 2015 and 2017 from Figure 3 [15]. To be conservative, we assumed an average shading level of $38 \%$, the mean of $26 \%$ and $50 \%$, two of the shading intensities shown in Figure 3 [15]. Reading in the graph the pertinent values and calculating, a shading level of $38 \%$ delivered an average tuber yield variation of $23.4 \%$, which we rounded to $23 \%$. We decided to apply no further uncertainty factor due to the following: although, with respect to the availability of the solar resource, our latitude of Seville is more advantageous than the latitude of Germany [15], this is cancelled-out by the fact that our early potato crop season is shifted towards winter.

\section{Appendix E.9. Tomato}

The data compiled in Table 1 [32] indicate no tomato yield variation between fullsunlight and shade ( $60 \%$ light). To be conservative, we considered a $-5 \%$ in yield, to account for the fact that Hernández et al.'s experiment [32], although at the same latitude than ours, was conducted inside a greenhouse.

\section{References}

1. Assessment of the Draft National Energy and Climate Plan of Spain. Commission Staff Working Document 2019-262 Final; European Commission: Brussels, Belgium, 2019.

2. Assessment of the Draft National Energy and Climate Plan of Italy. Commission Staff Working Document 2020-911; European Commission: Brussels, Belgium, 2020.

3. Red Eléctrica de España. Renewable Energy in the Spanish Electricity System-2019. 2020. Available online: www.ree.es/en (accessed on 19 March 2021).

4. Goetzberger, A.; Zastrow, A. On the coexistence of solar-energy conversion and plant cultivation. Int. J. Sol. Energy 1982, 1, 55-69. [CrossRef]

5. Dupraz, C.; Marrou, H.; Talbot, G.; Dufour, L.; Nogier, A.; Ferard, Y. Combining solar photovoltaic panels and food crops for optimising land use: Towards new agrivoltaic schemes. Renew. Energy 2011, 36, 2725-2732. [CrossRef]

6. Marrou, H.; Wery, J.; Dufour, L.; Dupraz, C. Productivity and radiation use efficiency of lettuces grown in the partial shade of photovoltaic panels. Eur. J. Agronomy 2013, 44, 54-66. [CrossRef]

7. Valle, B.; Simonneau, T.; Sourd, F.; Pechier, P.; Hamard, P.; Frisson, T.; Ryckewaert, M.; Christophe, A. Increasing the total productivity of a land by combining mobile photovoltaic panels and food crops. Appl. Energy 2017, 206, 1495-1507. [CrossRef]

8. Schindele, S.; Trommsdorff, M.; Schlaak, A.; Obergfell, T.; Bopp, G.; Reise, C.; Braun, C.; Weselek, A.; Bauerle, A.; Högy, P.; et al. Implementation of agrophotovoltaics: Techno-economic analysis of the price-performance ratio and its policy implications. Appl. Energy 2020, 265, 114737. [CrossRef]

9. Dinesh, H.; Pearce, J.M. The potential of agrivoltaic systems. Renew. Sustain. Energy Rev. 2016, 54, 299-308. [CrossRef]

10. SolarPower Europe. Agri-PV: How Solar Enables the Clean Energy Transition in Rural Areas. Briefing Paper. Available online: www.solarpowereurope.org (accessed on 29 December 2020).

11. Bellini, E. Special Solar Panels for Agrivoltaics. 2020. Available online: https://www.pv-magazine.com/2020/07/23/specialsolar-panels-for-agrivoltaics/ (accessed on 19 March 2021).

12. Hassanpour Adeh, E.; Selker, J.S.; Higgins, C.W. Remarkable agrivoltaic influence on soil moisture, micrometeorology and water-use efficiency. PLoS ONE 2018, 13, e0203256. [CrossRef] [PubMed]

13. Expósito, A.; Berbel, J. Agricultural irrigation water use in a closed basin and the impacts on water productivity: The case of the Guadalquivir river basin (southern Spain). Water 2017, 9, 136. [CrossRef]

14. Eurostat. Agri-environmental indicator-irrigation. Statistics Explained. 16/4/2019 (data from February 2019). p. 10. Available online: https:/ / ec.europa.eu/eurostat/statistics-explained/ (accessed on 19 March 2021).

15. Schulz, V.S.; Munz, S.; Stolzenburg, K.; Hartung, J.; Weisenburger, S.; Graeff-Hönninger, S. Impact of Different Shading Levels on Growth, Yield and Quality of Potato (Solanum tuberosum L.). Agronomy 2019, 9, 330. [CrossRef]

16. MAPA Avance del Anuario de Estadística 2019. 2020 Ministerio de Agricultura, Pesca y Alimentación. Available online: https:/ / www.mapa.gob.es (accessed on 19 March 2021).

17. Weselek, A.; Ehmann, A.; Zikeli, S.; Lewandowski, I.; Schindele, S.; Högy, P. Agrophotovoltaic systems: Applications, challenges, and opportunities. A review. Agron. Sustain. Dev. 2019, 39, 35. [CrossRef]

18. Cell Solar. Polycristalline 60 Cells CSP270-290W. Available online: www.cellsolar-energy.com (accessed on 29 December 2020).

19. Oberhofer, A. Spinnanker (Spider-Shaped Anchor). European Patent EP 1750020 B2, 7 February 2007.

20. Beck, M.; Bopp, G.; Goetzberger, A.; Obergfell, T.; Reise, C.; Schindele, S. Combining PV and food crops to agrophotovoltaicoptimization of orientation and harvest. EUPVSEC Proc. 2012, 1, 4096-4100.

21. NREL. System Advisor Model (SAM); 2020.11.29-R1, SSC 252.; National Renewable Energy Laboratory: Golden, CO, USA, 2020. 
22. SMA. Sunny HighPower Peak 3. Available online: https://www.sma.de/en/products/solarinverters/sunny-highpower-peak3 .html (accessed on 19 March 2021).

23. SISIFO. On-line Simulator of PV Systems. Solar Energy Institute of the Universidad Politécnica de Madrid. Web Service Supported by the European Commission with the H2020 Project MASLOWATEN. Available online: https:/ /www.sisifo.info/en/datainput (accessed on 2 March 2021).

24. Berbel, J.; Borrego-Marín, M.M.; Expósito, A.; Giannoccaro, G.; Montilla-López, N.M.; Roseta-Palma, C. Analysis of irrigation water tariffs and taxes in Europe. Water Policy 2019, 21, 806-825. [CrossRef]

25. FENACORE. Dossier de Prensa. Federación Nacional de Comunidades de Regantes. 2017. Available online: http://www. fenacore.org/empresas/fenacoreweb/documentos/DOSSIER\%20PRENSA\%20FENACORE\%202017.pdf (accessed on 19 March 2021).

26. Masia, S.; Susnik, J.; Marras, S.; Mereu, S.; Spano, D.; Trabucco, A. Assessment of irrigated agriculture vulnerability under climate change in Southern Italy. Water 2018, 10, 209. [CrossRef]

27. De Stefano, L.; Fornés, J.M.; López-Geta, J.A.; Villarroya, F. Groundwater use in Spain: An overview in light of the EU Water Framework Directive. Intl. J. Water Resour. Dev. 2015, 31, 640-656. [CrossRef]

28. Consejería de Medio Ambiente y Ordenación del Territorio. El Clima de Andalucía en el Siglo XXI. 2014 Junta de Andalucía. Available online: http://www.juntadeandalucia.es/medioambiente/site/portalweb/ (accessed on 29 December 2020).

29. TEXLA Renovables. Proyecto Planta Fotovoltaica Valle Inferior Solar 6 MWp. Comunidad de Regantes del Valle Inferior del Guadalquivir. 2018. Available online: www.valleinferior.es (accessed on 29 December 2020).

30. Marrou, H.; Dufour, L.; Wery, J. How does a shelter of solar panels influence water flows in a soil-crop system? Eur. J. Agronomy 2013, 50, 38-51. [CrossRef]

31. Barron-Gafford, G.A.; Pavao-Zuckerman, M.A.; Minor, R.L.; Sutter, L.F.; Barnett-Moreno, I.; Blackett, D.T.; Thompson, M.; Dimond, K.; Gerlak, A.K.; Nabhan, G.P.; et al. Agrivoltaics provide mutual benefits across the food-energy-water nexus in drylands. Nat. Sustain. 2019, 2, 848-855. [CrossRef]

32. Hernández, V.; Hellín, P.; Fenoll, J.; Flores, P. Interaction of nitrogen and shading on tomato yield and quality. Sci. Hortic. 2019, 255, 255-259. [CrossRef]

33. Berbel, J.; Expósito, A.; Gutiérrez-Martín, C.; Mateos, L. Effects of the Irrigation Modernization in Spain 2002-2015. Water Resour. Manag. 2019, 33, 1835-1849. [CrossRef]

34. Hernández-Mora, N.; Martínez Cortina, L.; Llamas Madurga, M.R.; Custodio Gimena, E. Groundwater Issues in Southern EU Member States. Spain Country Report; European Academies Science Advisory Council: Brussels, Belgium, 2007.

35. Comunidad de Regantes del Valle Inferior del Guadalquivir. Circular $n^{\circ} 1 / 2016$. 2016. Available online: http://valleinferior.es / circular-n-1-2016_aa14.html (accessed on 19 March 2021).

36. Rodríguez Díaz, J.A.; Poyato, E.C.; Pérez, M.B. Evaluation of Water and Energy Use in Pressurized Irrigation Networks in Southern Spain. J. Irrig. Drain. Eng. 2011, 137, 644-650. [CrossRef]

37. Fernández García, I.; Rodríguez Díaz, J.A.; Poyato, E.C.; Montesinos, P.; Berbel, J. Effects of modernization and medium term perspectives on water and energy use in irrigation districts. Agric. Syst. 2014, 131, 56-63. [CrossRef]

38. Sanchis-Ibor, C.; García-Mollá, M.; Avellà-Reus, L. Effects of drip irrigation promotion policies on water use and irrigation costs in Valencia, Spain. Hydrol. Res. 2017, 19, 165-180. [CrossRef]

39. Karkanis, A.; Ntatsi, G.; Kontopoulou, C.-K.; Pristeri, A.; Bilalis, D.; Savvas, D. Field Pea in European Cropping Systems: Adaptability, Biological Nitrogen Fixation and Cultivation Practices. Not. Bot. Horti Agrobot. Cluj-Napoca 2016, 44, 325-336. [CrossRef]

40. ITACYL. Plan de Monitorización de los Cultivos de Regadío en Castilla y León: Resultados de la Encuesta de Cultivos de la Campaña Agrícola 2013-2014. Junta de Castilla y León. 2015. Available online: www.inforiego.org (accessed on 19 March 2021).

41. Murugarren, N. Precios de la energía en la campaña 2012. Importancia de su negociación en la gestión de las comunidades de regantes. Navarra Agraria 2013, 7-11. Available online: www.navarraagraria.com (accessed on 19 March 2021).

42. OMIP. Market Bulletin MIBEL SPEL Solar Load (FTS). Available online: https: / /www.omip.pt/es/dados-mercado?date=2019-1 1-19\&product=EL\&zone=ES\&instrument=FTS\&maturity $=$ YR (accessed on 19 March 2021).

43. López-Prol, J.; Steininger, K.W.; Zilberman, D. The cannibalization effect of wind and solar in the California wholesale electricity market. Energy Econ. 2020, 85, 104552. [CrossRef]

44. Zhang, H.; Flottmann, S. Source-sink manipulation in canola indicates that yield is source limited. In Proceedings of the 17th ASA Conference, Hobart, Australia, 20-24 September 2015.

45. Barmon, N.C.; Bala, P.; Roy, U.K.; Azad, A.K. Growth and yield of carrot influenced by shading characters. Eco-friendly Agril. J. 2012, 5, 13-16.

46. Sekiyama, T.; Nagashima, A. Solar Sharing for Both Food and Clean Energy Production: Performance of Agrivoltaic Systems for Corn, A Typical Shade-Intolerant Crop. Environments 2019, 6, 65. [CrossRef]

47. Nasrullahzadeh, S.; Ghassemi-Golezani, K.; Javanshir, A.; Valizade, M.; Shakiba, M.R. Effects of shade stress on ground cover and grain yield of faba bean (Vicia faba L.). J. Food Agric. Environ. 2007, 5, 337-340.

48. Pereira, F.; Puiatti, M.; Finger, F.; Cecon, P. Growth, assimilate partition and yield of melon charenthais under different shading screens. Hortic. Bras. 2011, 29, 91-97. [CrossRef] 
49. Khan, M.A.A.; Larkin, A.; Singh, V.; Agarwal, Y.K. Impact of fertilizer levels on the growth and yield of onion (Allium cepa L.) under jatropha (Jetropha curcas L.) based agroforestry system. Int. Arch. App. Sci. Technol. 2019, 10, 107-113.

50. Gubbels, G.H. Quality, yield and seed weight of green field peas under conditions of applied shade. Can. J. Plant Sci. 1980, 61, 213-217. [CrossRef]

51. Seserman, D.M.; Veste, M.; Freese, D.; Swieter, A.; Langhof, M. Benefits of agroforestry systems for land equivalent ratio-case studies in Brandenburg and Lower Saxony, Germany. In Proceedings of the 4th European Agroforestry Conference-Agroforestry as a Sustainable Land Use, Nijmegen, The Netherlands, 28-30 May 2018; pp. 26-29.

52. Guaita-Pradas, I.; Blasco-Ruiz, A. Analyzing Profitability and Discount Rates for Solar PV Plants. A Spanish Case. Sustain. J. Rec. 2020, 12, 3157. [CrossRef]

53. Banco de España. 30-year Maturity Bonds. Spain. Financial Indicators. Daily Series. Available online: https://www.bde.es/ webbde/en/estadis/infoest/sindi.html (accessed on 6 November 2020).

54. Bolsas y Mercados Españoles. Annual Report. 2019. Available online: https://www.bolsasymercados.es/docs/inf_legal/ing/ economico/2019/IA-BME-2019-Eng.pdf (accessed on 19 March 2021).

55. Infrontanalytics. Levered/Unlevered Beta of SMA Solar Technology AG. Available online: https://www.infrontanalytics.com/ fe-EN/40278ED/SMA-Solar-Technology-AG/Beta (accessed on 29 December 2020).

56. Trommsdorff, M. An Economic Analysis of Agrophotovoltaics: Opportunities, Risks and Strategies towards a More Efficient land Use. Master's Thesis, University of Freiburg, Freiburg, Germany, 2016.

57. Stein, A. Utility-Scale Fixed-Tilt PV vs. Single-Axis Tracker PV: NEMS Projections to 2050. Capstone Paper. Master's Thesis, Johns Hopkins University, Baltimore, ML, USA, 2018. Available online: https://jscholarship.library.jhu.edu/handle/1774.2/59881 (accessed on 26 November 2020).

58. Amaducci, S.; Yin, X.; Colauzzi, M. Agrivoltaic systems to optimize land use for electric energy production. Appl. Energy 2018, 220, 545-561. [CrossRef]

59. IDAE. Ahorro y Eficiencia Energética en la Agricultura de Regadío. 2005. Available online: www.idae.es (accessed on 19 March 2021).

60. González Ruiz, J.I.; Descalzo Benito, M.J. Electricity Regulations in Spain: Overview. Thomson Reuters Practical Law. Available online: https: / / uk.practicallaw.thomsonreuters.com/4-529-8116? transitionType=Default\&contextData=(sc. Default)\&firstPage= true\#co_anchor_a808110 (accessed on 29 December 2020).

61. Wang, H.X.; Muñoz-García, M.A.; Moreda, G.P.; Alonso-García, M.C. Optimum inverter sizing of grid-connected photovoltaic systems based on energetic and economic considerations. Renew. Energy 2018, 118, 709-717. [CrossRef]

62. Nishizawa, T.; Ito, A.; Motomura, Y.; Ito, M.; Togashi, M. Changes in fruit quality as influenced by shading of netted melon plants (Cucumis melo L. 'Andesu' and 'Luster'). J. Jpn. Soc. Hort. Sci. 2000, 69, 563-569. [CrossRef]

63. Willockx, B.; Herteleer, B.; Cappelle, J. Techno-economic study of agrivoltaic systems focusing on orchard crops. In Proceedings of the EUPVSEC 2020 online Conference, online, 2 September 2020.

64. Schachinger, M. Module Price Index. 2020. Available online: www.pv-magazine.com/module-price-index (accessed on 4 December 2020).

65. Renovables Arlumi, S.L. Anteproyecto Planta Fotovoltaica 44.95 MWn La Torre 40 S.L. 2017. Available online: https: / / www.juntadeandalucia.es/export/drupaljda/tramite_informacion_publica/20/07/ANTEPROYECTO\%20PFV\%20LA\%20 TORRE\%2040.pdf (accessed on 19 March 2021).

66. Sueta, H.E.; Mocelin, A.; Zilles, R.; Obase, P.F.; Boemeisel, E. Protection of photovoltaic systems against lightning. Experimental verifications and techno-economic analysis of protection. In Proceedings of the XII SIPDA-International Symposium on Lightning Protection, Belo Horizonte, Brazil, 7-11 October 2013; pp. 442-447.

67. Cclcomponents. SMA DC String Combiner Box for STP/SHP Inverters. Available online: https:/ /www.cclcomponents.com/ sma-solar-dc-string-combiner-box-16-f2-s (accessed on 4 December 2020).

68. Vartiainen, E.; Masson, G.; Breyer, C. PV LCOE in Europe 2014-30-Final Report. 2015 European PV Technology Platform Steering Committee. PV LCOE Working Group. Available online: www.eupvplattform.org (accessed on 19 March 2021).

69. Vartiainen, E.; Masson, G.; Breyer, C.; Moser, D.; Román Medina, E. Impact of weighed average cost of capital, capital expenditure, and other parameters on future utility-scale PV levelised cost of electricity. Prog. Photovolt. Res. Appl. 2020, 28, 439-453. [CrossRef]

70. Esgueva, N.A. Línea de Conexión a 20 kV, Centro de Trasformación y Planta de Generación Fotovoltaica en Valdeolivas (Cuenca). Bachelor's Thesis, Universidad Carlos III de Madrid, Madrid, Spain, 2016. Available online: https://e-archivo.uc3m.es/handle/ 10016/24446 (accessed on 4 December 2020).

71. Eurostat. Labour Cost Levels by NACE. Available online: https:/ / ec.europa.eu/eurostat/web/labour-market/labour-costs (accessed on 29 December 2020).

72. Más que Máquinas Agrícolas. El Blog de Maquinaria de la Revista Agricultura. Costes de Externalización de Labores. Precios de Trabajos y Faenas Agrícolas. 2014. Available online: http:/ / www.masquemaquina.com/2014/01/costes-de-externalizacion-delabores-y.html (accessed on 29 December 2020).

73. Ministerio de Industria. Turismo y Comercio RD 1544/2011, de 31 de octubre, por el que se Establecen los Peajes de Acceso a las Redes de Transporte y Distribución que Deben Satisfacer los Productores de Energía Eléctrica; BOE 276; Ministerio de Industria, Turismo y Comercio: Madrid, Spain, 2011. 
74. TOTAL Gas y Electricidad España SAU. Huertos Solares: Venta a Mercado o PPAs. 2019. Available online: https://www. totalenergia.es/es / pymes/blog/huerto-Solar-parque-fotovoltaico-venta-energia-mercados-ppa (accessed on 29 December 2020)

75. MAPA. Resultados Técnico-Económicos de Cultivos Hortícolas 2016; Ministerio de Agricultura, Pesca y Alimentación: Madrid, Spain, 2020.

76. MAPAMA. Resultados Técnico-Económicos de Cultivos Herbáceos 2015; Ministerio de Agricultura y Pesca, Alimentación y Medio Ambiente: Madrid, Spain, 2017.

77. Consejería de Economía-Consejería de Empleo. Texto Articulado del Convenio Colectivo Provincial de Sevilla Para las Faenas Agrícolas, Forestales y Ganaderas 2017-2021. Boletín Oficial de la Provincia de Sevilla, 267. 2018 Junta de Andalucía. Available online: http:/ / www.juntadeandalucia.es/empleo/mapaNegociacionColectiva / descargarDocumento?uuid=d093aafe-ec99-11 e8-94d4-b70735927673 (accessed on 4 December 2020). 